\title{
Autocratic Survival Strategies: Does Oil Make a Difference?
}

\author{
${ }^{1}$ Hamburg Universität, Fakultat Wirtschafts- und Sozialwissenschaften, Economics, Von-Melle-Park 5, Hamburg, Cermany, \\ E-mail: phoebe.wasfy.ishak@uni-hamburg.de
}

\begin{abstract}
:
This paper examines the behavior of dictators when faced by an imminent threat of being overthrown in oil abundant countries. In the short run, the dictator's survival strategies is argued to be confined to public spending and repression, whereas the choice of their levels is conditional upon the intensity of the mass threat (i.e. civil protest vs. mass violence) and the size of oil wealth. The empirical results indicate a possibility of mixing between spending and repression, and that oil wealth allows for differences in their employed levels in face of the same threat. Using a dataset of authoritarian regimes in 88 countries from 1981 to 2006, I found that mass violence is handled through increasing both spending and repression, whereas civil protest is only met by repression. Furthermore, greater oil wealth is found to provide a wider fiscal space to relatively increase spending, but only at low and intermediate levels of mass threats. As the threats intensify, the effect of oil wealth dissipates and oil wealth dictatorships behave the same as their non-oil wealth counterparts.
\end{abstract}

Keywords: H50, P48, Q34, D74

DOI: $10.1515 /$ peps-2018-0043

\section{Introduction}

Recently, there has been a revived interest in exploring the link between oil rents and authoritarian regimes survival, with the bulk of literature suggesting that oil dictatorships are more likely to withstand political power challenges than their non-oil counterparts. ${ }^{1}$ With oil proceeds, dictators have the financial privilege that could allow them to neutralize mass threats by doling out resources on public goods, enhancing repressive capacities, providing less freedoms and reducing the need for political institutions (Ghandhi \& Przeworski, 2007; Mesquita \& Smith, 2010; Ross, 2001). However, dictators in general do not always follow the same strategy, when defending their thrones. The leader, acting rationally, will always choose the strategy that allows him to preserve his power at the lowest cost based on the severity of the political threat and the size of their financial resources, particularly oil wealth. ${ }^{2}$ For instance, the variation in the dictators' responses to preeminent threats can be depicted amid the 2011 Arab uprisings. Dictators facing ongoing revolutions or even imminent threats of it embarked different responses. In Tunisia and Egypt, the dictators, upon losing the support of their armed forces, decide to peacefully step down handing the authority to transitional governments guarded by the military. In Syria and Libya, results turned violent with both Bashar al-Assad and Muammar Gaddafi fiercely refusing to concede following the escalating instabilities and vowed instead to resort to force to crush protestors. In contrast, Gulf countries, with the exception of Bahrain, have been able to placate potential opposition through raising state salaries, providing new state jobs, revoking proposed subsidies cuts and offering direct handouts to citizens. In Saudi Arabia, for example, in February and March 2011, King Abdullah announced new spending plans of more than $\$ 100$ billion. $^{3}$

Oil driven spending may have allowed leaders in Gulf countries to shield their palaces from mass discontent, but in low oil production states, leaders decided to either step down or vowed to defeat the protesters, which could imply that a higher size of oil rents makes spending more allured to repression. Furthermore, the resolution made by some leaders to step down came as a last resort, after repressive forces, promises to cut prices and to allow more political freedoms have all failed to make protestors withdraw their demands for change. ${ }^{4}$ A matter that reveals the existence of short-term survival strategies, mainly spending and repression, as opposed to long-term ones in the form of freedoms or political concessions. Both remarks insatiate an important question: Under which circumstances will a particular survival strategy (-ies) become mostly effective to deter power challenges from below? As such, will a dictator follow the same measures when dealing with a peaceful small-scale protest as when facing a nationwide revolution? In this article, I argue that the resort to 
one strategy is rather conditional upon the type of posed mass threat, the dictator's time horizon (short run vs. long run) and the size of oil wealth.

Mass threats in dictatorships differ in type and severity, ranging from peaceful gatherings to violent acts of defiance and creating in turn political instabilities. Such instabilities affect the dictator's time horizon, forcing him to take short run responses that could substantially differ from the ones taken over a longer period of time. In the short run, the dictator's options are limited to the use of financial rewards (i.e. spending) and repressing defected groups (Wintrobe, 1998; Acemoglu \& Robinson, 2000; Annett, 2001), while in the long run, spending and repression, being financially costly to sustain, could relaxed for a less costly strategies such as suppression of freedoms or agreements for power sharing (Conrad, 2011; Ghandhi \& Przeworski, 2007; Mesquita \& Smith, 2010). For oil dependent dictatorships, a greater oil wealth can have the potential to allow the dictator to adopt different defense mechanisms than a dictator with limited or no oil revenues. By relaxing their budget constraints, oil revenues may lead dictators to increase spending and employ less repression.

Such disaggregation of types of the mass threats taking into account the length of the response period and size of oil wealth is widely overlooked in analyzing the dictator's behavior in general and the implications of oil wealth in particular. First, the institutional explanation for dictatorial stability leaves out the length of period available for a dictator to take action. When political instabilities are not taken into account, the relationship is underspecified, for not assessing the appropriateness of institutional reform within a short run horizon. Second, previous cross-country empirical studies estimating the impact of oil rents on spending, as a mechanism for regime durability, ignored the existence of political threats and did not account for repression (or other strategy) as a possible substitute (Morrison 2009; 2015; Ross, 2001; Wantchekon \& Jensen, 2004). Third, using measures for oil dependence (i.e. oil exports as a percentage of GDP) does not allow for testing the distributive and repressive differences among oil dictatorships based on the size of their population.

To the best of my knowledge, there are three studies that specifically analyzed the short term respond to political threats, which is either consumption or repression. The first is the theoretical model of Wintrobe (1998), where he argued that the short run response to a fall in mass loyalty is to repress. However, the type and severity of the mass threat was rather left unspecified in his model. The second study is by Annett (2001), where he found that political instabilities increase public spending to absorb dissidence. But, his indicator for instability was conflating less intense incidences of instabilities with violent events, and does not distinguish elite threats from mass threats by grouping coups with revolutions. As such, it fails to discern the corresponding impact for each threat type on spending, besides depending on cross-sectional analysis, which carries the concern on whether the casual mechanism can be confidently identified. Thirdly, Acemoglu and Robinson (2000) theoretically focused on the respond of dictators to revolutions via repression. In these studies, the type of state finance in influencing the leader's decision was left analyzed and except for Wintrobe (1998), there has been a mutually exclusive employment of either spending or repression to quench mass threats, rather than allowing for mixing between both depending on the intensity of the threat.

To address these analytic shortcomings and further push the research frontier, this article has two main goals: (1) investigate the dictator's short run response to different mass threats, (2) investigate whether the oil dictators' response shall differ from their non-oil counterparts and among each other, (3) analyze the possibility of mixing between repression and spending. Hence, I first estimate the simultaneous within-country effect of the civil protest and mass violence indices on public spending and repression levels. Then, I tackle the impact of the size of oil wealth on the resulting outcomes. Using time series-cross section data from 88 authoritarian countries between 1981 and 2006 and correcting for simultaneity, I found that mass violence is countered by both more spending and repression, and civil protest is only met by repression. Moreover, greater oil wealth is only found to provide a wider fiscal space to relatively increase spending at low and intermediate levels of threats. However, as threats intensify, the effect of oil wealth dissipates and oil dictatorships behave the same as their non-oil counterparts. Furthermore, oil wealth have no impact on repression, whether when accounting for threats or not, revealing that oil wealth may not alter the repressive stance of dictators and push them to substitute spending for repression. In general, repression is shown to crowd out the financial resources available to support public spending, whereas public spending does not seem to reduce the level of repression employed.

The outline of this paper is as follows. In the first section, the different types of mass threats that exist in dictatorships are discerned along with the dictator's available short run and long run responses, followed by a discussion on how a dictator can employ spending and repression in responding to mass threats in the short run. Next, I discuss how oil dictatorships could differ from their non-oil counterparts and among themselves in terms of financial endowments, which in turn might influence their corresponding survival strategies. In the fourth and fifth sections, data and methodology for estimating mass threats indices and for testing the proposed hypothesis are discussed. Sections six and seven present the results of employed models and robustness tests, and finally section eight concludes. 


\section{Dictatorial threats and survival strategies}

Dictators' main aim is to preserve their power in the direst dismal conditions, where power challenges are posed from different actors and on various amplitudes, leaving the dictator in a constant state of anxiously defending his throne (Svolik, 2012). Such situation is commonly referred as "the dictator's dilemma" which arises; when the dictator is not sure whether his people, both mases and elites, genuinely support him or only show a commanded support, especially in the absence of rules for succession and power alteration, leading to an ever present sense of insecurity (Wintrobe, 1998). To ease this mission, the dictator must carefully identify the source and estimate the severity of each political threat, upon which he can determine the suitable type of response. Given this fact, autocrats face two types of threats: those originating from their ruling elites and those coming from the masses (Gandhi, 2008; Ghandhi \& Przeworski, 2007; Svolik, 2012). Generally, a dictator responds to a specific potential threat with the following strategies or a combination of them: public spending, repression, freedoms and power sharing agreements (e.g. creating legislatures or providing opposition more political freedoms) (Conrad, 2011; Gandhi, 2008; Ghandhi \& Przeworski, 2007; Mesquita \& Smith, 2010; Wintrobe, 1998). Nevertheless, not all strategies are feasible in the short run. For instance, establishing political institutions as a guarantee for power sharing requires longer periods of negotiations especially in the presence of powerful elites and opposition groups, since they alter the rules of the game and force the dictator to concede part of his powers to keep his throne, a process that unfolds over time and not instantaneously. In other words, the severity of the power threats can shorten the dictator's time horizon pushing him to take short-term actions that differ substantially from long-term strategies that aim at uprooting sources of the threat. Knowing that, it makes sense to differentiate between short run and long run dictators' responses. Following Wintrobe (1998), Annett (2001), and Acemoglu and Robinson (2000), the most effective strategies to implement in the short run are spending and repression. ${ }^{5}$ To reduce the complexity pertaining to having different forms of threats and strategies, the focus of this study would be on disentangling the different forms of mass threats and analyzing only the corresponding short run dictator's response, which is the mix between spending and physical repression.

Bottom up threats stemming from the masses vary in nature and form. This implies that small-scale or peaceful anti-government gatherings like protests and strikes aimed at demonstrating sentiments of discontent with the function of the government should be distinguished from more organized violent acts of defiance. In this regard, Conrad (2011) and Vreeland (2008) emphasized the role of the organization of masses in influencing the dictator's respond, where more organized defected groups are met by more spending and more repression. Protests can show up spontaneously with leaderless masses suddenly taking into the streets at their own discretion. Hence, the leader's short run response shall be an immediate resort to force, since the protests are rather diffused and has little effect on the longevity of the regime (Conrad, 2011; Wintrobe, 1998). Repression has in this context an effective deterrence effect, since it discourages other groups from taking similar discourses. ${ }^{6}$ Mass violence such as revolutions, on the other hand, requires more organized groups to defy the state. The immediate resort to repression in this case has eminent consequences. On one hand, engaging in state violence could lead to an escalation of more violent acts against the state that can be perceived as a sign of regime incompetence and provoke military coups to bring stability back (Escribà-Folch, 2013; Wintrobe, 1998). On the other hand, once mass violence erupts, it means that participators have already solved to manage their collective action problems (Escribà-Folch, 2013). Alternatively, the dictator can respond in a divide and conquer fashion by increasing public spending to placate public support for anti-state groups and trying to stimulate the acquiescence of their leaders with material spoils (Annett, 2001; Mesquita \& Smith, 2010). A third strategy could entail a mix between repression and spending, such that both spending and repression are allowed to increase in respond to mass violence. For instance, more repression can be directed to specific defected groups such as armed factions, while more spending is doled on other sectors to uproot potential support to these groups. Being financially costly though subject spending and repression to trade-offs, such that the employment of one strategy causes a change in the level of provision for the other especially if the dictator's is running under budget constraints (Caselli \& Cunningham, 2009; Conrad, 2011; Wintrobe, 1998).

In sum, power conflicts are always present in dictatorships and in order for the leader to defend his palace, he must carefully define the source of threat and evaluate its severity. However, in contrast to previous studies (e.g. Acemoglu \& Robinson, 2000; Mesquita \& Smith, 2010; Wintrobe, 1998), where is always a clear cut a mutually exclusive employing of either spending or repression as a respond to mass threats, I argue here that there is also a possibility of mixing between both when the intensity of the threat is taken into account. Thus, not all resources are devoted to repression and the likelihood of doling out more resources on repression should never count out the possibility of increasing spending depending on the targeted group. Hence, depending on the intensity of the threat, the above discussion suggests the following testable hypotheses:

Hypothesis 1: In the short run, a dictator responds to civil protests with relatively less public spending and more repression independent of the size of oil wealth. 
Hypothesis 2: In the short run, a dictator responds to mass violence with relatively more public spending and more repression independent of the size of oil wealth.

\section{Oil and autocratic survival}

Dictators in oil-endowed countries resemble their opponents in other dictatorships, with regard to the constant present of power threats and the type of strategies employed to eliminate power challengers. However, they differ in the size of the financial resources available at their disposal, mainly the oil wealth, providing them the potential to behave differently in the short run in response to mass erupts. In other words, heterogeneities in the employed levels of repression and spending may exist based on the size of oil wealth.

As postulated by the rentier state theory, oil autocracies deploy oil proceedings in "buying off political consensus", hence obviating the need of the state to resort to taxation to generate the revenues required to reward their supporters. Such policy propels state autonomy and waives state accountability obligations in terms of setting up political institutions or allowing civil freedoms (Beblawi \& Luciani, 1987; Gandhi, 2008; Mahdavy, 1970; Mesquita \& Smith, 2010). The result is enclaved distributive economies residing upon capital-intensive sectors and having few forward and backward linkages with other sectors that eventually spur the consequent revenues on their population (Dunning, 2008). ${ }^{7}$ Given that, in order to preserve their grip on power, oil leaders generally depend on two main strategies: repression and cooptation (Wintrobe, 1998). On one hand, large investment in military and internal security apparatus shield the regime from possible popular upheavals (Ross, 2001). On the other hand, engaging in wide spread public spending can quench popular demands for political change (Wright, Frantz, \& Geddes, 2013). Likewise, relying on a repressive security apparatus is costly. In their study, Acemoglu, Ticchi, and Vindigni (2010) argue that natural resources can equip the leader to finance repression and thus increase likelihood of regime survival. Conversely, military can stage a coup against the current leader to install their military dictatorship and hence reduces chances of regime durability. However, the key advantage of having oil rents is that it can mediate the negative consequences of resorting to repression. Having a larger fiscal space can relax the dictator's budget constraint and allows for substituting public spending for force to tackle mass dissidence, thus making the former a more effective option in the short run and reduces the likelihood of violence escalation (Elbadawi \& Makdisi, 2013).

Yet, not all oil dictatorships are similar, for heterogeneities also exist among them in terms of the extent of oil wealth given the size of their population. Thus, although a country might be highly dependent on oil in terms of the percentage of oil exports to its total exports, or GDP, having big populations could dampen the country's total oil wealth per capita and in turn its distributive abilities. So, higher resource dependence is not equivalent to higher wealth. In their study, Basedau and Lacher (2006) found countries with high oil revenues per capita are more stable, experience less political instability than countries with low oil revenues per capita, even if both share the same level of oil dependence. Accordingly, a dictator resting on large oil wealth and facing low population, can afford spending on public goods, while maintaining a lower level of repression. In other words, the larger the size of oil resources per capita, the better off the authoritarian leaders, since higher resources can be distributed to their smaller population, thereby deterring incentives of rebellion and making repression not their first favored option (Elbadawi \& Makdisi, 2013). ${ }^{8}$ To conclude, differences in the financial privileges between oil-endowed and non-oil autocracies as well as within oil autocracies themselves may influence the dictator's behavior towards social upheavals in the short run in terms of the employed levels of spending and repression. Hence, taking into account the size of oil wealth, the following hypotheses are tested:

Hypothesis 3: A greater size of oil wealth increases spending and reduce repression, independent of the size of mass threats.

Hypothesis 4: In the short run, an oil dictator responds to civil protests by higher public spending and lower repression relative to non-oil dictator.

Hypothesis 5: In the short run, an oil dictator responds to mass violence by higher public spending and lower repression relative to non-oil dictator.

\section{Mass threats in dictatorships: measurement and estimated indices}

Mass threats in this study are defined as "any peaceful or violent mass attempts aimed at overthrowing the head of the state". Hence, unlike previous empirical literature on political instabilities (Alesina \& Perotti, 1996; Cukierman, Edward, \& Tabellini, 1992), the propensity of observing a leader turnover is not necessary, but only an event that threatens to bring down the dictator is sufficient. Building on this logic, an index for political instabilities is constructed to capture different dimensions of mass threats, mainly their less and more violent 
forms, and allowing to disentangle various factors that could endanger the survival of a dictator (Hibbs Jr, 1973; Vanieries \& Gupta, 1986). Therefore, instances that reflect elite's defections and internal palace attempts to topple the leader such as cabinet shuffles and coups are excluded (Jong-a-Pin, 2009). Accordingly, the following indicators were selected: assassinations, general strikes, guerrilla warfare, riots, revolutions, anti-government demonstrations, civil war and minor civil conflicts. Data sources are Cross-National Time-Series Data Archive (CNTS) taken from Databanks International (Databanks International, 2005) and International Peace Research Institute (Gleditsch, Wallensteen, Eriksson, Sollenberg, \& Strand, 2002). Based on data availability and in align with other employed indicators, the period of analysis covers the years 1981-2006. ${ }^{9}$

Each indicator on its own constitute an imperfect reflection of mass threats. For instance, a country could be rendered stable in a certain period due to the lack of civil wars. However, when taking into account the frequent occurrence of strikes and riots, the picture can dramatically change. In my model, it is necessary to differentiate between the severity of social disruptions that would force the dictator to resort to either public spending or repression and to group together factors of similar nature. In contrast to previous studies in which principal component analysis (PCA) was used (Alesina \& Perotti, 1996; Perotti, 1996; Blanco \& Grier, 2009), I employ instead explanatory factor analysis (EFA) to build the index (Annett, 2001; Jong-a-Pin, 2009). EFA differs in the sense that it assumes an underlying model that could explain the unobserved latent variable (in our case mass threats) and extracts only common variance to the observed indicators taking into account the existence of unique variance that pertains only to the single indicator. Definitions of the used indicators and the operationalization of explanatory factor analysis are found in Online Appendices A and B.

The results of the factor analysis give rise to two indices of political instabilities steaming from the populace during the period (1981-2006), namely civil protest and mass violence. The two indices exhibit low correlation among them, which indicate that each corresponds to a different dimension of political instability, despite the fact that the correlation coefficient is significantly different from 0 (see Table 2 in Online Appendix B). To ease interpretation, the scores of the two indices are multiplied by minus 1 so that higher values would indicate more stability.

For further insights, Figure 1 outlines the indices scores across world regions based on decade-average scores. ${ }^{10}$ It indeed shows that the state of political stability differs across different parts of the world and even within regions overtime. It also shows that a region could show more stability on one dimension relative to the other. For instance, the most stable region is appears to be the Middle East in terms of civil protest based on average score over the three decades, but it was replaced by Europe in case of mass violence.
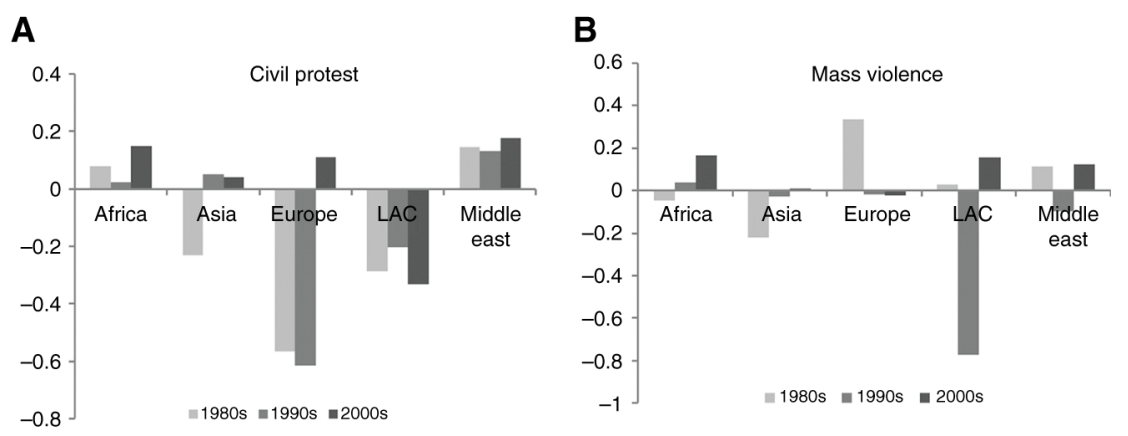

Figure 1: Social stability across and within regions.

To get a first snapshot of the relationship between oil and stability, Figure 2 classifies countries into oil producing dictatorships, non-oil dictatorships and richest quartile of oil producing dictatorships in per capita terms (i.e. oil rich low population). Oil dictatorships refer to countries combing between active oil production and authoritarian regimes. Countries are classified to be "High oil wealth" countries, if the whole-period-average of their oil wealth corresponds to the highest $3^{\text {rd }}$ quartile (73 percentile) ${ }^{11}$ Based on decade-average scores, oil dictatorships in general seem to witness relatively more civil protests and violence than non-oil dictatorships, whereas the richest segment of oil dictatorships enjoys relatively more stability in both aspects than both groups. This rather confirms the existence of heterogeneity among oil producing countries lending credence to a potential presence of a threshold effect for the impact of oil rents on preserving political stabilities (Basedau \& Lacher, 2006). Such threshold is a function of the amount of received oil rents and the size of the population. 
A

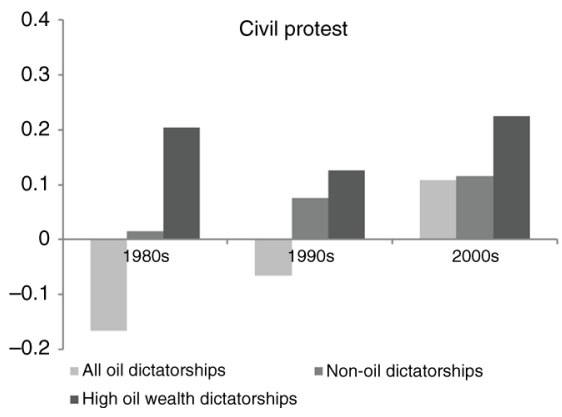

B

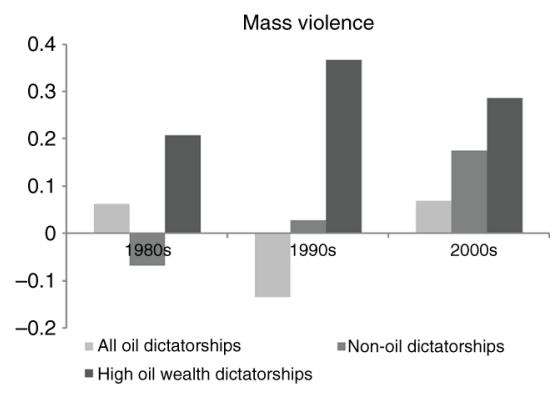

Figure 2: Social stability across oil and non-oil dictatorships.

\section{Empirical approach}

\subsection{Model specification}

To examine the effect of mass threats and oil endowments on the different political paths a dictator can take to foster his throne, the preceding hypotheses regarding public spending and state repression as possible mechanisms to nullify existing threats in the short run are tested. I start with two separate dynamic linear regression models with country and year fixed effects. Our dependent variables are the levels of public spending and repression regressed over the two indices of mass threats along with the measure for oil wealth (per capita):

$$
\begin{aligned}
& \text { Spending }_{i t}=\beta_{o}+\beta_{1} M T_{i t-1}+\beta_{2} \text { Oil }_{i t-2}+\beta_{3} X_{1, i t}+\alpha_{i}+\delta_{t}+\varepsilon_{1, i t} \\
& \text { Repression }_{i t}=\beta_{o}+\beta_{1} M T_{i t-1}+\beta_{2} \text { Oil }_{i t-2}+\beta_{3} X_{2, i t}+\alpha_{i}+\delta_{t}+\varepsilon_{2, i t}
\end{aligned}
$$

where $\alpha_{i}$ and $\delta_{t}$ are country and year fixed effects, MT is the two constructed mass threats indices, Oil is the measure for a country's oil wealth in per capita terms, $X$ is a set of all other control variables that may affect the two dependent variables and $\varepsilon_{i t}$ is an error term. As previously indicated, it is also possible that the dictator can resort to both tools at the same time depending on the severity of the threat, hence simultaneous changes in levels of spending and repression can occur. In addition, being both financially costly imply that the employment of one strategy necessitates a change in the provision of the others, hence the two survival strategies are deemed to be interdependent (Conrad, 2011). To capture this interdependence and correct for simultaneity, I estimate a simultaneous equation model (SEM) in which the two endogenous variables spending and repression shall appear as the dependent variable in one equation, while being included as additional explanatory variables in the other two equations. The structural equations for SEM take the following form:

$$
\begin{gathered}
\text { Spending }_{i t}=\beta_{1} Z_{1, i t}+\gamma_{1} \text { Rep }_{i t}+\alpha_{i}+\delta_{t}+\varepsilon_{1, i t} \\
\text { Repression }_{i t}=\beta_{2} Z_{2, i t}+\gamma_{2} \text { Spend }_{i t}+\alpha_{i}+\delta_{t}+\varepsilon_{2, i t}
\end{gathered}
$$

where $Z_{1}$ and $Z_{2}$ are the set of covariates including $M T$ indices and Oil that affect each dependent variable. This system of equations is estimated using least squares two-stage instrumental-variables regression with country and year fixed effects, where each of the two endogenous spending and repression variables is instrumented by their lagged levels. Since it is a dynamic simultaneous system, there might be some concern regarding a potential suffering from Nickel bias (Nickell 1981), which arises when a lagged dependent variable is included along with OLS fixed-effects in large $\mathrm{N}$-small $\mathrm{T}$ samples, causing correlation between the former and the error term. To address this concern, the system of equations is also estimated using system-GMM (Blundell \& Bond, 1998). To illustrate, in the first stage, the below equations are estimated using all the covariates $\left(Z_{1}, Z_{2}\right)$ from equations (3) and (4) to get the fitted values for Spend and Rep:

$$
\text { Spending }=\alpha_{1} Z_{1, i t}+\alpha_{2} Z_{2, i t}+\varepsilon_{4}
$$




$$
\text { Repression }=\alpha_{3} Z_{1, i t}+\alpha_{4} Z_{2, i t}+\varepsilon_{5}
$$

In the second stage, the fitted values obtained from equations (5) and (6) are then substituted for Spend and Rep in equations (3) and (4) to get unbiased estimates of $\gamma_{1}$ and $\gamma_{2}$. The identification of this system requires specific instruments for spending and repression to be included in one equation but excluded from the other, $Z_{1}$ and $Z_{2}$. These specific instruments are the lagged levels of spending and repression.

Recognizing that a potential feedback effect might exist in the sense that instances of mass threats may drive leaders to increase spending and repression to prevent an escalation of the situation and at the same time, higher spending and repression can bring stabilization to the regime. This in turn renders mass threats indices to become endogenous and allows the causality to work in either direction. ${ }^{12}$ Adding to that, oil wealth as a function of the ability to extract and distribute oil can be affected by popular uprisings which may cause disruption in oil production and adversely affect the proceeding rents. Furthermore, a dictator facing ongoing instabilities may want to increase oil production to maximize his revenues (Wright et al., 2013). Both incidences make oil wealth endogenous as well. To address that, the MT indices are lagged by 1 year, whereas the oil variable is 2-years lagged to help reduce the reverse feedback effect and allows for possible lags in the reaction of the dictator to political threats. Finally, to test the hypotheses that oil dictatorships can behave differently to non-oil dictators in face of mass threats depending on the size of oil wealth, each of the MT indices is interacted with oil wealth to examine whether the impact of oil wealth on spending and repression, and so the dictator's response, varies with the intensity of mass threats. ${ }^{13}$

\subsection{Data and descriptive analysis}

I use time series-cross sectional (TSCS) data on autocratic regimes and the type of leadership from Cheibub Jose, Ghandi, and Vreeland (2010a) (2010a and 2010b). CGV distinguishes between different types of dictatorships based on the characteristics of their leaders, namely civilian, military or monarch. The main sample consists of 88 countries for the years 1981 until 2006. ${ }^{14}$ Periods of major civil war, foreign occupation or the collapse of state authority are excluded on the grounds of failing to be qualified as either democratic or dictatorship. ${ }^{15} \mathrm{I}$ identify these periods using the dataset on autocratic breakdown and regime transition from Geddes, Wright and Frantz (Geddes, Wright, \& Frantz, 2014), whereas cases of civil wars are not excluded if the governor still holds grip on most of his territory. Table 1 shows the descriptive analysis for the variables from the baseline specification.

Table 1: Summary statistics.

\begin{tabular}{lrrrrr}
\hline Variable & N & Mean & SD & Min & Max \\
\hline Year & 1298 & 1994.58 & 7.07 & 1981 & 2006 \\
Civil protest index & 1294 & 0.03 & 0.99 & -0.27 & 15.52 \\
Mass violence index & 1294 & -0.04 & 0.83 & -0.49 & 5.88 \\
Oil wealth per capita (in current US\$) & 1298 & 572.72 & 1812.78 & 0 & 18115.42 \\
Oil wealth per capita (log) & 1298 & 2.52 & 3.02 & 0 & 9.80 \\
Public spending (log) & 1298 & 20.88 & 1.88 & 16.58 & 26.67 \\
Repression (inverse) & 1298 & 3.92 & 2.02 & 0 & 8 \\
GDP per capita (log) & 1298 & 7.43 & 1.27 & 4.88 & 11.11 \\
All dictatorships & 26 & 86.38 & 12.21 & 70.00 & 108.00 \\
Oil dictatorships & 26 & 46.69 & 2.85 & 42.00 & 51.00 \\
Oil dictatorships (\%) & 26 & 54.68 & 4.92 & 47.17 & 61.11 \\
Oil dictotrships (annual change) & 25 & -0.28 & 1.57 & -4 & 3 \\
\hline
\end{tabular}

On average, oil dictatorships constitute around 54.7 percent of all sample dictatorships and over the whole period, the share ranged between 47.2 percent and 61.1 percent. The majority of oil dictators has, on average, a civilian background (49.3 percent) followed by military personnel (29.2 percent) and finally, monarchy (21.5 percent). The observed number of dictatorships has relatively high standard deviation of 11 points, while number of oil dictatorships shows a low variation of 2.7 points. This is confirmed in Figure 3 , which traces the evolution of dictatorships over the sample period and shows that while dictatorships in general were witnessing a steady decline in number, oil dictatorships posed resilient with average change hovering around -0.28 points. 


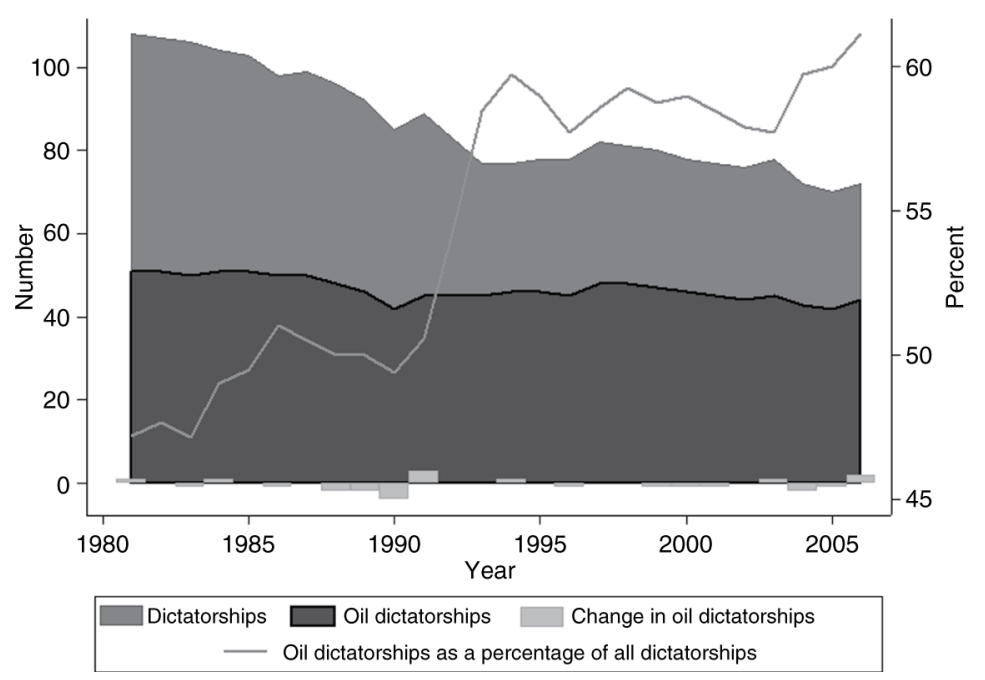

Figure 3: The number and change in oil dictatorships, 1981-2006.

Summary statistics presented in Table 1 show that the average oil revenues per capita is around 573 current US dollars, with very large cross-country and time variation. If we restrict the sample to only oil producing countries, the average oil rents per capita jumps to 1614 current US dollars. The majority of dictatorships are associated with oil production. In 1068 out of 1298 dictator-year observation, a non-zero value of per capita oil revenues is observed. The maximum value of oil rents per capita is scored by Qatar.

To examine the effect of spending and repression as mechanisms to cool off mass political threats, Figure 4 and Figure 5 depict the change in the levels of spending and repression along with the average score of both mass threat indices in a number of countries. In Nigeria and Algeria (Figure 4), the increase in the level of threats occurred parallel to the decline in government spending, whereas their consequent fall was witnessed shortly after the boost in spending. A close co-movement can also be seen between threats and repression. The rise in repression goes hand in hand with the upsurge in the threats level in both countries. In Indonesia (Figure 5), the steady rise in spending kept the level of threats low. However, once a sudden fall in spending was recorded, threats aggravated and at the same time, repression picked up. Gabon has witnessed little instabilities all over the whole period, but the uptick in threats followed the steady decline in spending and was brought back down by increased repression. The latter remained quite high even when the spending started to rise again.
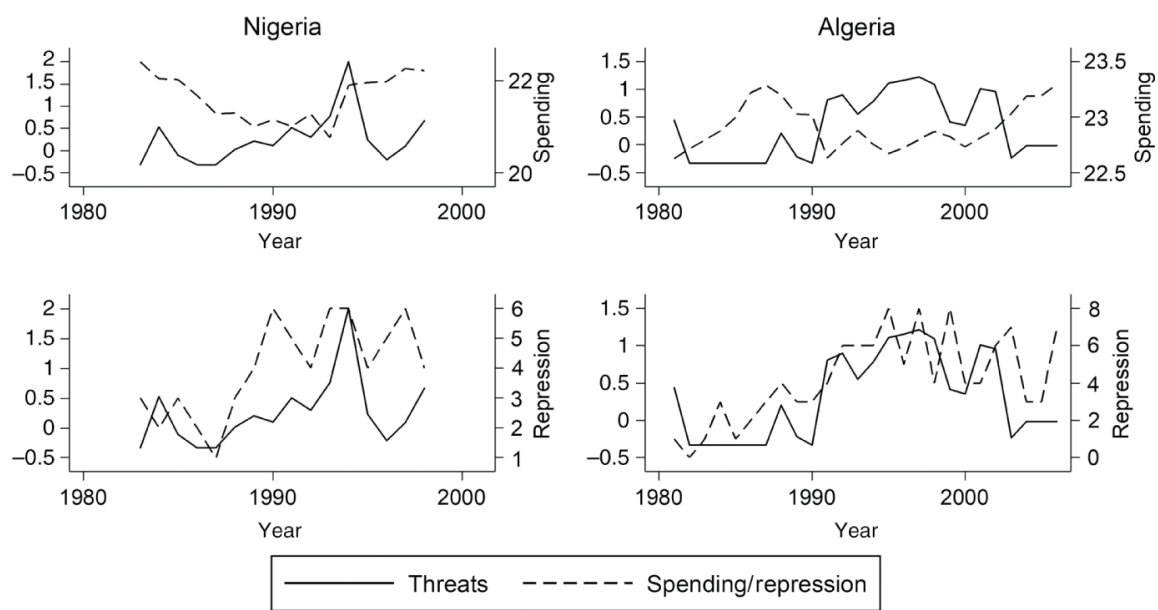

Figure 4: Mass threats, spending and repression. 

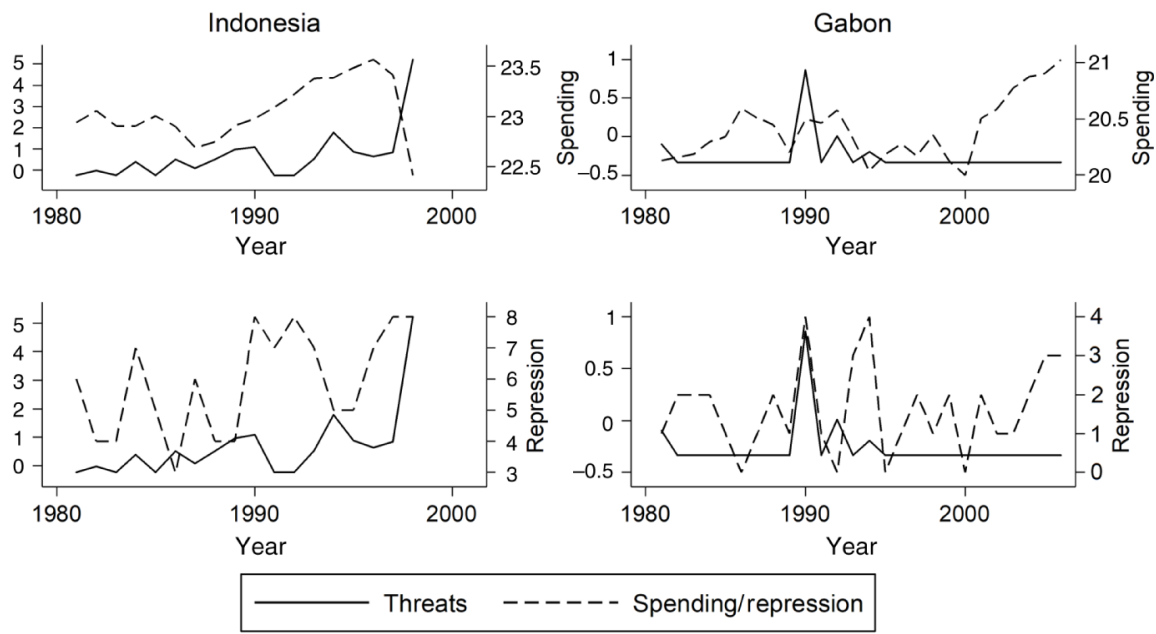

Figure 5: Mass threats, spending and repression (cont.).

To measure public spending, an indicator that captures only current state spending on public services, such as health, education, infrastructure...etc., should be the one of interest. Current expenditures are presumed to be a first choice for a dictator to correct for political failures, since dictators have full control over state funds allocations and because current spending have an immediate effect on cooling off disgruntled demands especially during times of critical unrest, unlike capital expenditures which require time to show an impact. To measure that, the "General government final consumption (current US Dollars)" indicator obtained from World Bank's World Development Indicators is used (World Bank 2016). It covers all government current expenditures including expenditure on national defense and security, but exclude military capital expenditure. State Repression is measured by Physical integrity index (Cingranelli, Richards, \& Clay, 2014) build up from torture, extrajudicial killing, political imprisonment and disappearance indicators, and ranging from 0 (no respect) to 8 (full respect). The index is rescaled so that 0 would then indicate no government repression and 8 indicate highest government repression.

The main independent variables are the composite index of mass threats divided into two sub-indices and oil income per capita. To measure oil, I rely on (log) total oil income per capita data (measured in current US Dollars) taken from Haber and Menaldo dataset Haber and Menaldo (2011). This measure is obtained by multiplying the level of oil production by world oil prices and then dividing by the number of population. The explanatory power of this measure allows for assessing whether the responses of oil producing dictators differ from non-oil producing and as well as within oil producers themselves. By incorporating the size of the population, it evaluates in turn the distributive capabilities of oil producing countries. ${ }^{16}$ Finally, because the ability of the leader to finance public spending depends on the overall economic environment, it is expected that wealthier countries are better equipped to increase consumption spoils to their populace. ${ }^{17}$ Thus, a control variable for country's wealth measured by GDP per capita is included (World Bank 2016). ${ }^{18}$

\section{Empirical results}

Table 2 reports the results of two separate fixed-effects models with public spending and repression as dependent variables. The coefficients for mass violence and civil protest are only positive and statistically significant in the repression models. Hence, ignoring the trade-offs between strategies suggest that dictators are more likely in the short run to resort to repression irrespective of the type of the threat. Oil wealth, on the other hand, has a statistically significant positive effect on spending only. This comes in line with Morrison (2015), who found a positive relationship between non-tax revenue, including oil revenues, and government spending. ${ }^{19}$ The results are quite close across the OLS and system-GMM estimations.

Table 2: Effect of mass threats and oil wealth on public spending and repression.

\begin{tabular}{|c|c|c|c|c|}
\hline \multirow[t]{3}{*}{ Model } & \multicolumn{2}{|c|}{ Spending } & \multicolumn{2}{|c|}{ Repression } \\
\hline & (1) & (2) & (3) & (4) \\
\hline & OLS & SYS-GMM & OLS & SYS-GMM \\
\hline Civil protest $_{t-1}$ & $\begin{array}{l}0.002 \\
(0.005)\end{array}$ & $\begin{array}{l}0.028 \\
(0.021)\end{array}$ & $\begin{array}{l}0.173^{* *} \\
(0.067)\end{array}$ & $\begin{array}{l}0.261^{* * *} \\
(0.059)\end{array}$ \\
\hline
\end{tabular}




\begin{tabular}{|c|c|c|c|c|}
\hline Mass violence $_{t-1}$ & $\begin{array}{l}0.006 \\
(0.009)\end{array}$ & $\begin{array}{l}0.017 \\
(0.012)\end{array}$ & $\begin{array}{l}0.227^{* *} \\
(0.092)\end{array}$ & $\begin{array}{l}0.421^{* * *} \\
(0.134)\end{array}$ \\
\hline \multirow{2}{*}{$\begin{array}{l}\text { Oil Per capita } \\
(\log )_{t-2}\end{array}$} & $0.026^{* *}$ & $0.021^{*}$ & 0.016 & 0.075 \\
\hline & $(0.012)$ & $(0.014)$ & $(0.068)$ & $(0.049)$ \\
\hline GDP per capita t $-1_{1}$ & $\begin{array}{l}0.0001^{* *} \\
(0.0001)\end{array}$ & $\begin{array}{l}0.0001 \\
(0.0001)\end{array}$ & $\begin{array}{l}-0.0001 \\
(0.000)\end{array}$ & $\begin{array}{l}-0.0001^{* * *} \\
(0.0001)\end{array}$ \\
\hline \multirow[t]{2}{*}{$\begin{array}{l}\text { Dependent } \\
\text { variable }_{t-1}\end{array}$} & $0.818^{* * *}$ & $0.949^{* * *}$ & $0.390^{* * *}$ & $0.486^{* * *}$ \\
\hline & $(0.034)$ & $(0.033)$ & $(0.044)$ & $(0.127)$ \\
\hline $\operatorname{AR}(1)$ & & 0.00 & & 0.00 \\
\hline $\operatorname{AR}(2)$ & & 0.367 & & 0.983 \\
\hline $\begin{array}{l}\text { Hansen overid test, } p \\
\text { value }\end{array}$ & & 0.435 & & 0.269 \\
\hline $\begin{array}{l}\text { Number of } \\
\text { observations }\end{array}$ & 1296 & 1296 & 1296 & 1296 \\
\hline Adjusted R2 & 0.793 & & 0.285 & \\
\hline Number of countries & 88 & 88 & 88 & 88 \\
\hline Country FE & Yes & Yes & Yes & Yes \\
\hline Year FE & Yes & Yes & Yes & Yes \\
\hline
\end{tabular}

The method of estimation in columns 1 and 3 is least squares; columns 2 and 4 is system-GMM; $t$-statistics reported in parentheses are based on Huber-robust standard errors clustered at the country level. In column 2, the lagged dependent variable is instrumented by only its second lag at the differenced equation and its first lag at the level equation. In column 3 , the lagged dependent variable is instrumented by only its third lag at the difference equation and second lag at the level equation. Country and year fixed effects are not reported. The asterisks denote: ${ }^{*} p<0.10,{ }^{* *} p<0.05,{ }^{* * *} p<0.01$.

To account for the simultaneous changes in both spending and repression given the presence of mass threats and test the cross-tradeoffs, Table 3 shows the results for the two-stage equation model estimated by least squares and system-GMM with spending and repression instrumented by their lagged levels. Column 1 reports the estimates for the average effect of mass violence on spending, which is positive and statistically significant, while the coefficient for civil protest is positive but weakly significant (let alone not robust) and with much smaller magnitude than mass violence. This suggests that, independent of oil wealth, dictators are more likely in the short run to dole out more resources in terms of spending and repression when confronted with violent groups than when dealing with peaceful or small-scale acts of disobedience, confirming Annett (2001) results that state also increases spending in face of political unrest. Based on column 2, the size of the effect on spending implies that one-point standard deviation increase in mass violence increases the log of spending by 0.02 points in the short run and by around 0.11 points in the long run. Having positive and significant point estimates of oil wealth suggests that higher oil wealth per capita is associated with higher spending. A higher level of oil wealth may therefore allow for directing domestic consumption towards buying political consent. For instance, a one-point standard deviation increase in the log of oil revenues leads to a 0.09 point increase in the log of government spending in the short run and 0.47 point increase in the long run.

Table 3: Effect of mass threats and oil on public spending and repression.

\begin{tabular}{|c|c|c|c|c|c|c|}
\hline \multirow[t]{3}{*}{ Model } & \multicolumn{3}{|c|}{ Spending } & \multicolumn{3}{|c|}{ Repression } \\
\hline & (1) & (2) & (3) & (4) & (5) & (6) \\
\hline & IV-2SLS & IV-2SLS & SYS-GMM & IV-2SLS & IV-2SLS & SYS-GMM \\
\hline \multirow[t]{2}{*}{ Civil protest $_{t-1}$} & $0.011^{*}$ & 0.012 & $0.027^{*}$ & $0.174^{* * *}$ & $0.118^{* *}$ & $0.388^{* *}$ \\
\hline & $(0.006)$ & $(0.009)$ & $(0.016)$ & $(0.066)$ & $(0.058)$ & $(0.151)$ \\
\hline \multirow[t]{2}{*}{ Mass violence $_{t-1}$} & $0.022^{* *}$ & $0.021^{*}$ & $0.020^{*}$ & $0.230^{* * *}$ & $0.235^{* * *}$ & $0.553^{* * *}$ \\
\hline & $(0.010)$ & $(0.011)$ & $(0.011)$ & $(0.088)$ & $(0.073)$ & $(0.135)$ \\
\hline \multirow[t]{2}{*}{ Oil per capita $(\log )_{t-2}$} & $0.028^{* *}$ & $0.028^{* *}$ & $0.017^{* *}$ & 0.024 & 0.041 & 0.120 \\
\hline & $(0.013)$ & $(0.012)$ & $(0.008)$ & $(0.071)$ & $(0.074)$ & $(0.115)$ \\
\hline \multirow{2}{*}{$\begin{array}{l}\text { Civil protest } t_{t-1}{ }^{*} \text { oil per } \\
\text { capita }_{t-2}\end{array}$} & & 0.001 & 0.001 & & $-0.046^{*}$ & -0.003 \\
\hline & & $(0.004)$ & $(0.004)$ & & $(0.024)$ & $(0.031)$ \\
\hline \multirow{2}{*}{$\begin{array}{l}\text { Mass violence }{ }_{t-1}{ }^{*} \text { oil per } \\
\text { capita }_{t-2}\end{array}$} & & 0.002 & 0.005 & & -0.038 & -0.027 \\
\hline & & $(0.004)$ & $(0.004)$ & & $(0.024)$ & $(0.043)$ \\
\hline \multirow[t]{2}{*}{ GDP per capita t $-1_{1}$} & $0.0001^{* *}$ & $0.0001^{* *}$ & 0.0001 & -0.0001 & -0.0001 & $-0.0001^{* * *}$ \\
\hline & $(0.000)$ & $(0.000)$ & $(0.000)$ & $(0.000)$ & $(0.000)$ & $(0.000)$ \\
\hline Spending $_{t}$ & & & & -0.093 & -0.078 & -0.123 \\
\hline
\end{tabular}




\begin{tabular}{|c|c|c|c|c|c|c|}
\hline & & & & $(0.156)$ & $(0.149)$ & $(0.285)$ \\
\hline Repression $_{\mathrm{t}}$ & $\begin{array}{l}-0.035^{* * *} \\
(0.012)\end{array}$ & $\begin{array}{l}-0.034^{* * *} \\
(0.013)\end{array}$ & $\begin{array}{l}-0.006 \\
(0.006)\end{array}$ & & & \\
\hline Dependent variable $_{t-1}$ & $\begin{array}{l}0.811^{* * *} \\
(0.031)\end{array}$ & $\begin{array}{l}0.810^{* * * *} \\
(0.031)\end{array}$ & $\begin{array}{l}0.957^{* * *} \\
(0.021)\end{array}$ & $\begin{array}{l}0.387^{* * *} \\
(0.044)\end{array}$ & $\begin{array}{l}0.376^{* * *} \\
(0.042)\end{array}$ & $\begin{array}{l}0.341^{* * *} \\
(0.072)\end{array}$ \\
\hline First-stage F-statistic & 75.72 & 77.62 & & 606.46 & 606.18 & \\
\hline $\operatorname{AR}(1)$ & & & 0.000 & & & 0.000 \\
\hline $\operatorname{AR}(2)$ & & & 0.383 & & & 0.606 \\
\hline Hansen overid test, $p$ value & & & 0.990 & & & 0.204 \\
\hline $\begin{array}{l}\text { Joint F-statistic for } \\
\text { interaction terms, } p \text { value }\end{array}$ & & 0.81 & 0.34 & & 0.09 & 0.81 \\
\hline Number of observations & 1296 & 1296 & 1296 & 1296 & 1296 & 1296 \\
\hline Number of countries & 88 & 88 & 88 & 88 & 88 & 88 \\
\hline Country FE & Yes & Yes & Yes & Yes & Yes & Yes \\
\hline Year FE & Yes & Yes & Yes & Yes & Yes & Yes \\
\hline
\end{tabular}

The method of estimation in columns 1,2, 4 1nd 5 is two-stage least squares; columns 3 and 6 is two-stage GMM; $t$-statistics reported in parentheses are based on Huber-robust standard errors clustered at the country level. Oil per capita $(\log ) t-2$ in columns $2,3,5$ and 6 is the country's oil wealth at $t-2$ minus the average oil wealth among autocracies at $t-2$. In column 3 , the lagged dependent variable is instrumented by its second lag at the differenced equation and its first lag at the level equation. In column 6 , the lagged dependent variable is instrumented by all lags at level and differenced equation and "collapse" command is used to reduce the instrument set. Country and year fixed effects are not reported. The asterisks denote: ${ }^{*} p<0.10,{ }^{* * *} p<0.05,{ }^{* * *} p<0.01$.

In the repression models, the corresponding effects of both indices in column 4 are quite high, indicating that dictators do not hesitate in using force to root out potential threats independent of their severity and source and more repression is shown in face of organized violence than protest (Vreeland, 2008; Wintrobe, 1998). For instance in column 4, a one-point increase in violence leads to 0.23 -point increase in repression in the short run and around 0.59-point increase in the long run, compared to a short run 0.17-point increase in response to civil protest and a long run 0.45 -point. When it comes to oil wealth, it had on average a positive but insignificant effect on repression, a result that could reflect that leaders in oil wealthy countries do not differ from other dictators when it comes to the use of repression independent of type of threats. This partially coincides with Smith (2004) findings that repression do not fully account for explaining regime durability in oil dictatorships, for these countries employ the same level of repression as the rest of dictatorships. Columns 1 and 4 also reports the first-stage $F$-statistic for both models; the statistic is around 76 and 606 for spending and repression, respectively, which is above the threshold of 10 recommended by Staiger and Stock (1997), indicating that weak instruments does not represent a concern. Other results show that GDP per capita is positively significant in the spending model, meaning that dictators having more resources at their disposal can use them to solidify their rule by increasing consumption (Wintrobe, 1998). Finally, the results indicate that spending and repression adjust very quickly to changes, with the variation in their current levels being highly explained by their previous year's levels.

Interestingly to see that there is a statistically significant negative association between repression and spending in the spending referring to the financial constraints entailing the provision of both strategies. In fact, a 1point standard deviation increase in repression causes log of spending to reduce by 0.07 points in the short run and by 0.36 points in the long run. In contrast, the coefficient of spending in the repression model is negative, but statistically insignificant. This suggests that repression can crowd out the financial resources available to support public spending, whereas public spending does not seem to reduce the level of repression employed. In other words, repression can substitute spending, but spending cannot substitute repression. Other results show that GDP per capita is positively significant in the spending model, meaning that dictators having more resources at their disposal can use them to solidify their rule by increasing consumption (Wintrobe, 1998). Finally, the results indicate that spending and repression have reached their steady state levels (i.e. positive estimates), with the variation in their current levels being highly explained by their previous year's levels.

To test whether the size of the oil wealth relatively affects the spending and repression levels across different types and levels of threats, the $(\log )$ oil wealth is then interacted with indices of civil protest and mass violence. To take in account the variation within the oil producing countries and to ease interpretation, the $(\log )$ oil wealth is calculated as the country's oil wealth at $t-2$ minus the average oil wealth among autocracies at $t-2$. By this construction, we are now looking at the effect of political instabilities in an average oil producing country. The two-stage least squares results are shown in Table 3, columns 2 and 5. In the spending model, the coefficients of the main variables remained almost unchanged, both in significance and magnitude, except for civil protest, which posed insignificant. Hence, civil protests are less likely to be countered by more spending suggesting that using state coffers to satisfy protesters is seen to be a costly strategy (Conrad, 2011; Wintrobe, 1998). The conditioning variables were of expected positive sign but statistically insignificant. Similarly was the case in the repression model, with the conditioning variables having an expected negative signs, but either weakly or statistically insignificant point estimates. The $F$-test of the joint significance of the interaction terms fail to reject 
the null hypothesis that both term are not jointly different from zero in the spending model $(p$-value $=0.81)$, while in the repression model, the null hypothesis is barely rejected at 10 percent significance level model ( $p$ value $=0.09$ ). The size of the effect of protest and violence on repression, when conditional effects of oil wealth are taken into account has slightly changed. Based on column 5, a one-point increase in violence leads to 0.24point increase in repression in the short run and around 0.64-point increase in the long run, compared to a short run 0.12-point increase in response to civil protest and a long run 0.32-point. The columns also reports firststage $F$-statistic for both models and it is well above the recommended threshold. The results from system-GMM estimation, shown in columns 3 and 6, are very close to the original least squares results. As in the previous model, the resemblance of the estimated results across least squares and system-GMM is not surprising given the time dimension of the sample, where Nickel Bias becomes smaller when T is 20 years or more (Beck \& Katz, 2011)..$^{20}$

Nevertheless, such results do not provide any information about the responses of oil dictators given the type and size of mass threat. To analyze that, Figure 6 show the conditional marginal effects of a change in oil wealth on the levels of repression and spending at the different levels of mass threats based on models 2 and 5 in Table 3 together with 95\% confidence bands. Figure 6 A and C shows the conditional marginal effects of greater oil wealth on spending and repression at various intensity levels of civil protest. The solid line depicts a change in the marginal effect as the intensity of the threat goes up, indicating that countries with relatively greater oil wealth increase spending and reduce repression. However, the increase in spending is only significantly different from zero at very low levels on the $95 \%$ confidence interval and the reduction in repression is not statistically significant at all levels of mass threat. This indicates that at low levels of threats, a dictator with greater oil wealth can nullify the threats by relatively more spending, however as the threat intensifies, such marginal effect vanishes making the dictator behave the same as dictators with lower oil wealth. In contrast, a dictator with greater oil wealth responds with the same level of repression prevailing in low oil wealth countries at all levels of civil protest. Similarly, Figure 6 B and D shows the corresponding marginal effects of oil wealth at various levels of mass violence. The marginal effect on spending appears to be positive statistically significant at low and intermediate levels of mass threat, while the effect on repression is negative but insignificant at all levels of mass violence.
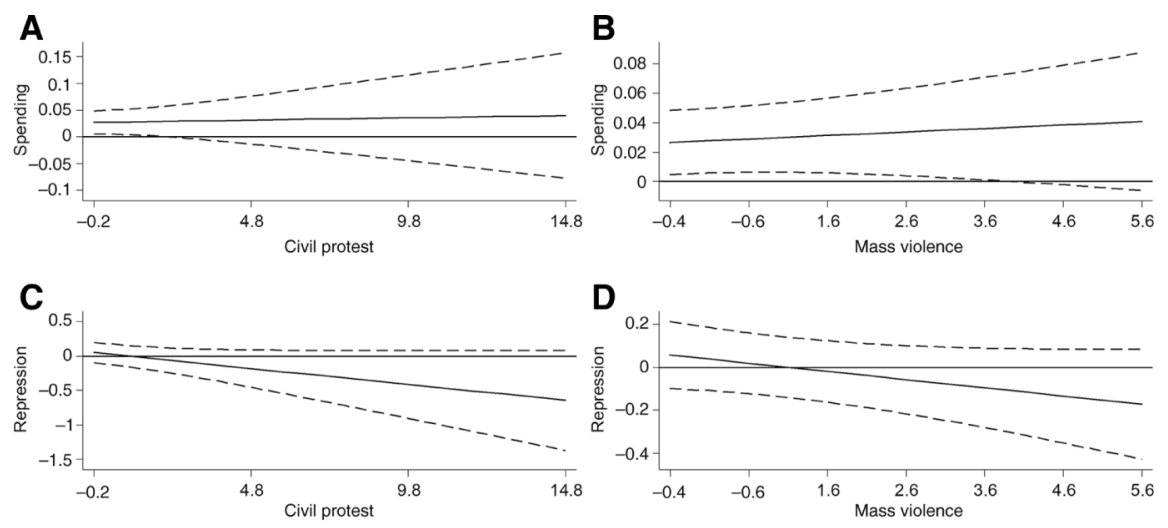

D

Figure 6: Conditional marginal effects at different levels of civil protest and mass violence.

In line with hypotheses 1 and 2, a dictator will respond in the short run with relatively more spending and repression in face of violence than in case of civil protest, independent of the size of oil wealth and civil protest are more likely to be met by increased repression only. Both results confirm the possibility of increasing both spending and repression, rather than preferring one to the other depending on the severity of the threat. In addition, oil dictators were found to differ from their non-oil counterparts in their financial capacities to engage in large scale spending given the size of their population, but in contrast to hypothesis 3 , they resemble the latter group in terms of their repressive stance independent of threats. Furthermore, the hypotheses on oil dictatorships stated that greater oil wealth allows countries to relatively increase spending and lower repression in face of mass threats. However, the results contradicts these hypotheses. In all incidences of mass threats, greater oil wealth had a relatively positive marginal impact on spending at low and intermediate levels of threats, while showing no difference on the level of employed repression as compared to non-oil dictators. This leads to an interesting result that all dictatorships exhibit the same behavior when faced by either extensive mass violence or civil protest and the financial advantage of having a greater of oil wealth vanishes as threat intensifies. Hence, there is no reason to believe that a very high size of oil wealth makes countries less repressive or drives them to substitute spending for force. The latter result is even more aligned with recent studies which found that resource windfalls may in contrast increase repression through relaxing the dictator's budget constraint against power challengers (Tsui, 2010) or because they increase the value of staying in power (Caselli \& Tesei, 2016). 


\section{Robustness tests}

In this section, the results from a number of performed robustness checks are reported. Specifically, I start with the two-stage least squares baseline specification in Table 3 (columns 2 and 5) and then apply the following modifications one at a time: (a) add institutional variables; (b) drop major oil producers (OPEC); (c) differentiate between boom and bust periods; (d) use alternative measures for oil wealth, government spending and repression. ${ }^{21}$

Freedoms concession or suppression can be an alternative strategy to either repression or spending. In addition, the ability of the populace to pose a threat to the dictator depends on the institutional setting inside the regime. For instance, people would be deterred from protesting if the expected retaliation, in terms of higher repression, would be severe. To account for these, a measure for the levels of civil freedoms is included, which assesses the state of freedoms of expression, associational and organizational rights and freedom of movement in given year (Freedom House, 2016). The inverse of this index is used, so that 1 would indicate no respect for civil freedoms and 7 indicate full respect. Furthermore, dictators may respond differently to threats depending on their background. In this regard, military dictatorships, as a ruling doctrine based on the "management of violence", have a competitive advantage in the use of force and in cases of political threats, more repression is employed (Wintrobe, 1998). On the contrary and despite their use of violence, civilian dictators and monarchs may rely more on the distribution of public goods and on maintaining patronage networks as their primary survival strategy (Wright et al., 2013). Therefore, a Military Leader dummy variable to control for the dictator's type is also included (Ghandhi \& Przeworski, 2006, 2007). Both institutional variables are lagged by 1 year to be consistent with the starting date of the mass threat.

The results are reported in Table 4. The results are identical to the baseline specification, where the sign and the statistical significance of each of the main independent variables remain the same. The Military Leader dummy variable had no significant effect on both spending and repression, whereas civil freedoms had a strong negative significant relationship with repression, but not with spending. As such, freedoms can an alternative to physical forms of state repression, but are less likely to be a substitute to spending. Additionally, in columns 3 and 6, we control for country-specific time trends to reduce potential omitted variable bias arising from focusing on the reduced form estimates. In this way, if political instabilities are not randomly distributed, including a country-specific time trend ensures that repression is not simply upward trending towards them. Our key estimates remain quantitatively and statistically the same. ${ }^{22}$

Table 4: Type of dictator, degree of civil freedoms and country-specific time trend.

\begin{tabular}{|c|c|c|c|c|c|c|}
\hline \multirow[t]{2}{*}{ Model } & \multicolumn{3}{|l|}{ Spending } & \multicolumn{3}{|c|}{ Repression } \\
\hline & $\begin{array}{l}\text { (1) } \\
\text { IV-2SLS }\end{array}$ & $\begin{array}{l}(2) \\
\text { IV-2SLS }\end{array}$ & $\begin{array}{l}\text { (3) } \\
\text { IV-2SLS }\end{array}$ & $\begin{array}{l}(4) \\
\text { IV-2SLS }\end{array}$ & $\begin{array}{l}\text { (5) } \\
\text { IV-2SLS }\end{array}$ & $\begin{array}{l}\text { (6) } \\
\text { IV-2SLS }\end{array}$ \\
\hline Civil protest $_{t-1}$ & $\begin{array}{l}0.012 \\
(0.009)\end{array}$ & $\begin{array}{l}0.012 \\
(0.009)\end{array}$ & $\begin{array}{l}0.012 \\
(0.009)\end{array}$ & $\begin{array}{l}0.120^{* *} \\
(0.058)\end{array}$ & $\begin{array}{l}0.108^{* *} \\
(0.055)\end{array}$ & $\begin{array}{l}0.120^{* *} \\
(0.057)\end{array}$ \\
\hline Mass violence $_{t-1}$ & $\begin{array}{l}0.021^{*} \\
(0.011)\end{array}$ & $\begin{array}{l}0.020^{*} \\
(0.011)\end{array}$ & $\begin{array}{l}0.021^{*} \\
(0.011)\end{array}$ & $\begin{array}{l}0.244^{* * * *} \\
(0.073)\end{array}$ & $\begin{array}{l}0.202^{* * * *} \\
(0.072)\end{array}$ & $\begin{array}{l}0.236^{* * *} \\
(0.073)\end{array}$ \\
\hline Oil per capita $(\log )_{t-2}$ & $\begin{array}{l}0.027^{* *} \\
(0.012)\end{array}$ & $\begin{array}{l}0.029^{* *} \\
(0.012)\end{array}$ & $\begin{array}{l}0.027^{* *} \\
(0.012)\end{array}$ & $\begin{array}{l}0.038 \\
(0.075)\end{array}$ & $\begin{array}{l}0.060 \\
(0.067)\end{array}$ & $\begin{array}{l}0.036 \\
(0.073)\end{array}$ \\
\hline $\begin{array}{l}\text { Civil protest } \\
\text { capita }_{t-2}\end{array}$ & $\begin{array}{l}0.001 \\
(0.004)\end{array}$ & $\begin{array}{l}0.001 \\
(0.004)\end{array}$ & $(0.004)$ & $\begin{array}{l}-0.045^{*} \\
(0.025)\end{array}$ & $\begin{array}{l}-0.040^{*} \\
(0.023)\end{array}$ & $\begin{array}{l}-0.046^{*} \\
(0.024)\end{array}$ \\
\hline $\begin{array}{l}\text { Mass violence }_{t-1}{ }^{*} \text { oil per } \\
\text { capita }_{t-2}\end{array}$ & $\begin{array}{l}0.002 \\
(0.004)\end{array}$ & $\begin{array}{l}0.002 \\
(0.004)\end{array}$ & $\begin{array}{l}0.002 \\
(0.004)\end{array}$ & $\begin{array}{l}-0.040^{*} \\
(0.024)\end{array}$ & $\begin{array}{l}-0.036 \\
(0.023)\end{array}$ & $\begin{array}{l}-0.039 \\
(0.024)\end{array}$ \\
\hline GDP per capita t -1 & $\begin{array}{l}0.0001^{* *} \\
(0.000)\end{array}$ & $\begin{array}{l}0.0001^{* *} \\
(0.000)\end{array}$ & $\begin{array}{l}0.0001^{* *} \\
(0.000)\end{array}$ & $\begin{array}{l}-0.0001 \\
(0.000)\end{array}$ & $\begin{array}{l}-0.0001 \\
(0.000)\end{array}$ & $\begin{array}{l}-0.0001 \\
(0.000)\end{array}$ \\
\hline Civil liberties $_{t-1}$ & & $\begin{array}{l}-0.013 \\
(0.011)\end{array}$ & & & $\begin{array}{l}-0.211^{* * *} \\
(0.051)\end{array}$ & \\
\hline Military dictator $_{t-1}$ & $\begin{array}{l}0.010 \\
(0.056)\end{array}$ & & & $\begin{array}{l}0.315 \\
(0.206)\end{array}$ & & \\
\hline Spending $_{\mathrm{t}}$ & & & & $\begin{array}{l}-0.092 \\
(0.152)\end{array}$ & $\begin{array}{l}-0.054 \\
(0.154)\end{array}$ & $\begin{array}{l}-0.078 \\
(0.150)\end{array}$ \\
\hline Repression $_{t}$ & $\begin{array}{l}-0.034^{* * *} \\
(0.013)\end{array}$ & $\begin{array}{l}-0.038^{* * *} \\
(0.013)\end{array}$ & $\begin{array}{l}-0.034^{* * *} \\
(0.013)\end{array}$ & & & \\
\hline Dependent variable $_{t-1}$ & $\begin{array}{l}0.810^{* * * *} \\
(0.031)\end{array}$ & $\begin{array}{l}0.811^{* * * *} \\
(0.032)\end{array}$ & $\begin{array}{l}0.810^{* * *} \\
(0.032)\end{array}$ & $\begin{array}{l}0.374^{* * *} \\
(0.042)\end{array}$ & $\begin{array}{l}0.350^{* * *} \\
(0.043)\end{array}$ & $\begin{array}{l}0.376^{* * *} \\
(0.042)\end{array}$ \\
\hline
\end{tabular}




\begin{tabular}{|c|c|c|c|c|c|c|}
\hline First-stage $F$-statistic & 76.99 & 67.09 & 78.02 & 633.21 & 607.58 & 594.70 \\
\hline $\begin{array}{l}\text { Joint F-statistic for } \\
\text { interaction terms, } p \text { value }\end{array}$ & 0.82 & 0.81 & 0.83 & 0.09 & 0.13 & 0.09 \\
\hline Number of observations & 1296 & 1296 & 1296 & 1296 & 1296 & 1296 \\
\hline Number of countries & 88 & 88 & 88 & 88 & 88 & 88 \\
\hline Country FE & Yes & Yes & Yes & Yes & Yes & Yes \\
\hline Year FE & Yes & Yes & Yes & Yes & Yes & Yes \\
\hline Country-specific time trend & No & No & Yes & No & No & Yes \\
\hline
\end{tabular}

The method of estimation is two-stage least squares; $t$-statistics reported in parentheses are based on Huber-robust standard errors clustered at the country level. Oil per capita $(\log ) t-2$ is the country's oil wealth at $t-2$ minus the average oil wealth among autocracies at $\mathrm{t}-2$. Country-fixed effects, year fixed effects and country-specific time trend are not reported. The asterisks denote: ${ }^{*} p<0.10,{ }^{* *} p<$ $0.05, * * * 00.01$

The value of oil wealth, being a function of oil prices and oil production, could be severely affected by downturns in international oil prices, i.e. bust periods. This could in turn damage the ability of the dictator to offer material spoils in exchange for political consent. On the other hand, boom periods generate expectations of higher subsequent public spending, which if not occurred, could lead to social unrest. Furthermore, higher oil prices can drive military actions against the regime, fed by the greed to capture the accumulated oil revenues. To examine that, Table 5 divides the sample into oil bust and boom periods. Bust period is defined as all years between 1986 and 1999 in which international oil prices were at their lowest (Barsky \& Kilian, 2004), while boom periods refers to the periods from 1981-1985 to 2000-2006. The downside of splitting the sample, however, is the entailed loss of observations, which can affect the results. Nevertheless, during bust period, mass violence remain positive and statistical significant, while oil wealth lost its significance in the spending model. The opposite occurs during the booms periods, with mass violence becoming insignificant and oil wealth gaining statistical significance. In the repression model, the effect of mass threats on repression remains the same during both periods, and the oil wealth's impact is still insignificant. This implies that during periods of financial crisis and the inability of oil revenues to fund public spending, public dissidence can support violence against the state. As such, the state responds mass violence with more spending to placate public support to it and also with more repression. During boom periods, the state is in a stronger financial position vis-à-vis opponents and therefore, refuses to tolerate mass violence and regards repression as the suitable respond.

Table 5: Oil bust and boom periods, and excluding OPEC Countries.

\begin{tabular}{|c|c|c|c|c|c|c|}
\hline \multirow[t]{2}{*}{ Model } & \multicolumn{3}{|c|}{ Spending } & \multicolumn{3}{|c|}{ Repression } \\
\hline & $\begin{array}{l}\text { Bust } \\
\text { period } \\
\text { (1) } \\
\text { IV-2SLS }\end{array}$ & $\begin{array}{l}\text { Boom } \\
\text { period } \\
(2) \\
\text { IV-2SLS }\end{array}$ & $\begin{array}{l}\text { Excluding } \\
\text { OPEC } \\
\text { (3) } \\
\text { IV-2SLS }\end{array}$ & $\begin{array}{l}\text { Bust } \\
\text { period } \\
\text { (4) } \\
\text { IV-2SLS }\end{array}$ & $\begin{array}{l}\text { Boom } \\
\text { period } \\
\text { (5) } \\
\text { IV-2SLS }\end{array}$ & $\begin{array}{l}\text { Excluding } \\
\text { OPEC } \\
\text { (6) } \\
\text { IV-2SLS }\end{array}$ \\
\hline Civil protest $_{t-1}$ & $\begin{array}{l}0.012 \\
(0.013)\end{array}$ & $\begin{array}{l}0.019 \\
(0.013)\end{array}$ & $\begin{array}{l}0.008 \\
(0.007)\end{array}$ & $\begin{array}{l}0.102^{*} \\
(0.059)\end{array}$ & $\begin{array}{l}0.261^{* * *} \\
(0.094)\end{array}$ & $\begin{array}{l}0.089 \\
(0.066)\end{array}$ \\
\hline Mass violence $_{t-1}$ & $\begin{array}{l}0.024^{*} \\
(0.014)\end{array}$ & $\begin{array}{l}0.037 \\
(0.024)\end{array}$ & $\begin{array}{l}0.018^{*} \\
(0.011)\end{array}$ & $\begin{array}{l}0.170^{* *} \\
(0.072)\end{array}$ & $\begin{array}{l}0.349^{* * *} \\
(0.153)\end{array}$ & $\begin{array}{l}0.185^{* * *} \\
(0.057)\end{array}$ \\
\hline Oil per capita $(\log )_{t-2}$ & $\begin{array}{l}-0.027 \\
(0.038)\end{array}$ & $\begin{array}{l}0.017^{*} \\
(0.011)\end{array}$ & $\begin{array}{l}0.026^{* *} \\
(0.012)\end{array}$ & $\begin{array}{l}-0.102 \\
(0.141)\end{array}$ & $\begin{array}{l}0.141 \\
(0.100)\end{array}$ & $\begin{array}{l}0.051 \\
(0.076)\end{array}$ \\
\hline $\begin{array}{l}\text { Civil protest } t_{t-1}{ }^{*} \text { oil per } \\
\text { capita }_{t-2}\end{array}$ & $\begin{array}{l}0.003 \\
(0.006)\end{array}$ & $\begin{array}{l}0.007 \\
(0.006)\end{array}$ & $\begin{array}{l}-0.001 \\
(0.003)\end{array}$ & $\begin{array}{l}-0.049^{* *} \\
(0.024)\end{array}$ & $\begin{array}{l}-0.038 \\
(0.055)\end{array}$ & $\begin{array}{l}-0.059^{* *} \\
(0.028)\end{array}$ \\
\hline $\begin{array}{l}\text { Mass violence }{ }_{t-1}{ }^{*} \text { oil } \\
\text { per capita }_{t-2}\end{array}$ & -0.003 & -0.005 & 0.002 & -0.029 & -0.048 & $-0.059^{* * *}$ \\
\hline & $(0.004)$ & $(0.006)$ & $(0.004)$ & $(0.026)$ & $(0.039)$ & $(0.019)$ \\
\hline GDP per capita $a_{t-1}$ & $\begin{array}{l}0.0001^{* * *} \\
(0.000)\end{array}$ & $\begin{array}{l}0.0001 \\
(0.000)\end{array}$ & $\begin{array}{l}0.0001^{* * * *} \\
(0.000)\end{array}$ & $\begin{array}{l}-0.0001 \\
(0.000)\end{array}$ & $\begin{array}{l}-0.0001 \\
(0.000)\end{array}$ & $\begin{array}{l}-0.0001 \\
(0.000)\end{array}$ \\
\hline Spending $_{t}$ & & & & $\begin{array}{l}0.140 \\
(0.340)\end{array}$ & $\begin{array}{l}-0.180 \\
(0.197)\end{array}$ & $\begin{array}{l}-0.063 \\
(0.146)\end{array}$ \\
\hline Repression $_{t}$ & $\begin{array}{l}-0.053^{* *} \\
(0.026)\end{array}$ & $\begin{array}{l}-0.038 \\
(0.026)\end{array}$ & $\begin{array}{l}-0.031^{* *} \\
(0.013)\end{array}$ & & & \\
\hline Dependent variable $_{t-1}$ & $\begin{array}{l}0.677^{* * *} \\
(0.037)\end{array}$ & $\begin{array}{l}0.883^{* * *} \\
(0.056)\end{array}$ & $\begin{array}{l}0.819^{* * *} \\
(0.034)\end{array}$ & $\begin{array}{l}0.287^{* * *} \\
(0.065)\end{array}$ & $\begin{array}{l}0.316^{* * *} \\
(0.057)\end{array}$ & $\begin{array}{l}0.388^{* * *} \\
(0.046)\end{array}$ \\
\hline First-stage $F$-statistic & 21.71 & 30.16 & 70.16 & 331.63 & 220.44 & 517.02 \\
\hline $\begin{array}{l}\text { Joint F-statistic for } \\
\text { interaction terms, } p \\
\text { value }\end{array}$ & 0.56 & 0.35 & 0.82 & 0.09 & 0.40 & 0.00 \\
\hline
\end{tabular}




\begin{tabular}{lllllll} 
Number of observations & 729 & 552 & 1158 & 729 & 552 & 1158 \\
Number of countries & 77 & 80 & 78 & 77 & 80 & 78 \\
Country FE & Yes & Yes & Yes & Yes & Yes & Yes \\
Year FE & Yes & Yes & Yes & Yes & Yes & Yes \\
\hline
\end{tabular}

The method of estimation is two-stage least squares; $t$-statistics reported in parentheses are based on Huber-robust standard errors clustered at the country level. Oil per capita $(\log ) t-2$ is the country's oil wealth at $t-2$ minus the average oil wealth among autocracies at $\mathrm{t}-2$. Columns 1 and 3 restrict sample to bust period (1986-1999); columns 2 and 4 restrict the sample to boom periods (1981-1985) and (2000-2006); Columns 3 and 6 exclude OPEC countries. Country and year fixed effects are not reported. The asterisks denote: ${ }^{*} p<0.10$, ${ }^{* *} p<0.05,{ }^{* * *} p<0.01$

Additionally, international oil prices are also affected by the internal political status in major oil world producers, which could cast is shadow on the value of oil returns. To address this concern, Table 5 excludes OPEC countries from the sample. The key estimates remain the same in the spending model, but civil protest lost its significance in the repression model. This could be rather due to the drop in the sample size. The $F$-test of the joint significance of the interaction terms rejects the null hypothesis that both terms are not jointly different from zero in the repression model. This, however, does not change our main conclusion that oil wealth does not drive the dictator to employ less repression, given the oil wealth variable is statistically insignificant.

Despite the fact that oil wealth enters the model 1 year before the start date of mass erupts, there might be still some concern regarding the full erogeneity of this measure, since production might be affected by mass erupts as well expectations for mass erupts. To address this, total oil reserves $(\log )$, as proxy for time-fixed measure of oil abundance, is used instead. This variable enters the empirical specification with 3 years lags to account for the possibility that having higher reserves do not automatically imply the ability to extract and produce oil, since the latter is also function of the degree of economic development, geography and trade relations. I also consider using 2, 4 and 5-years lags. The main results remain robust in all specifications in Table 6 


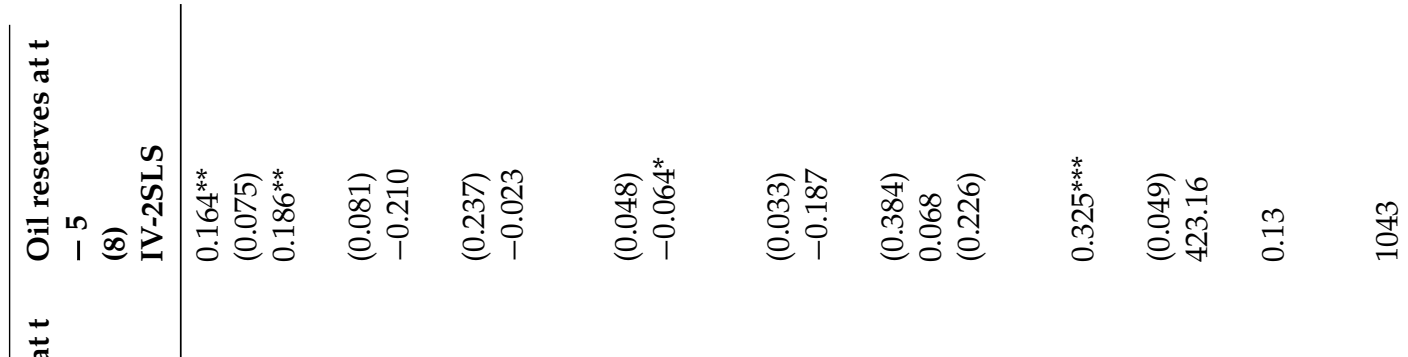

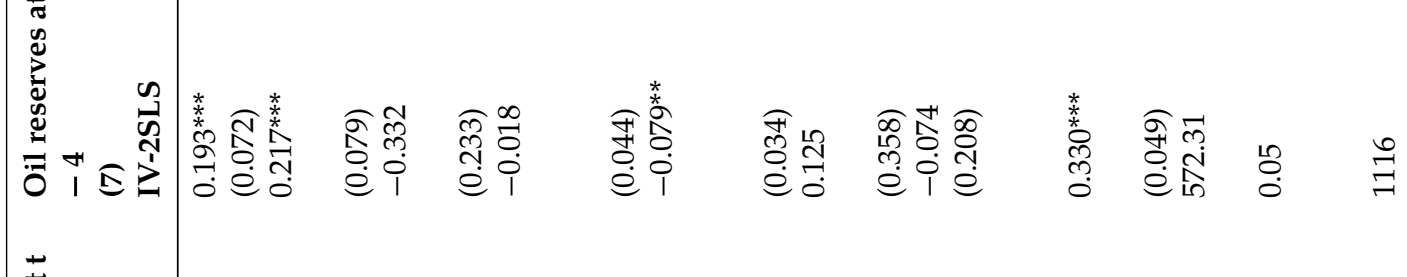

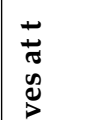

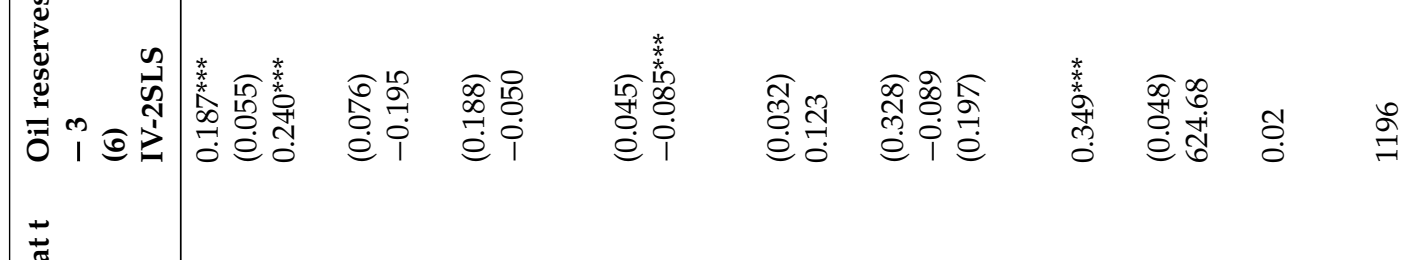

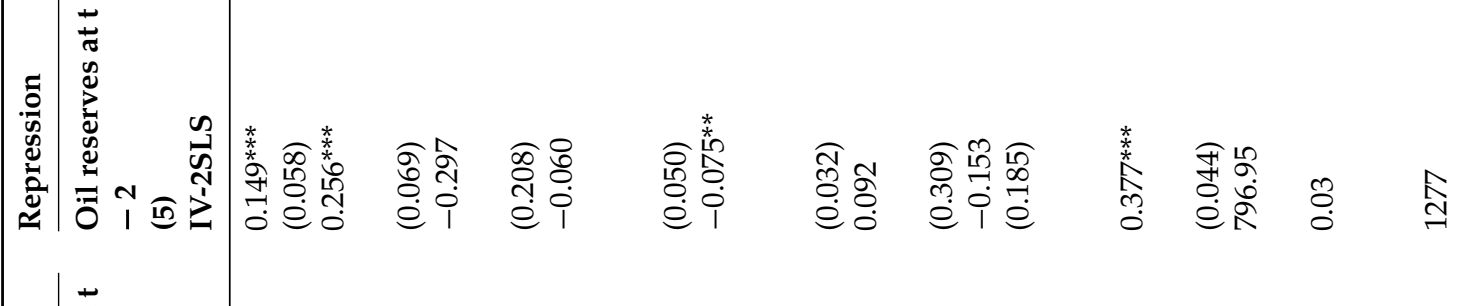

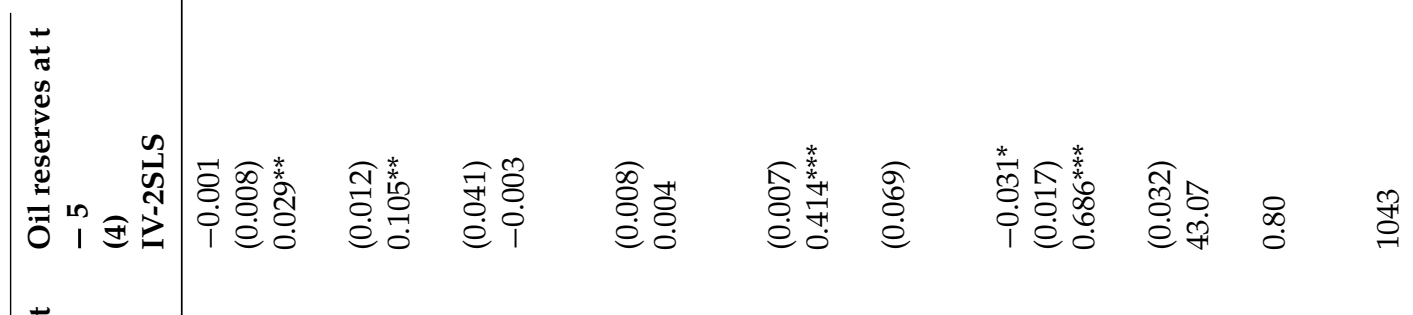

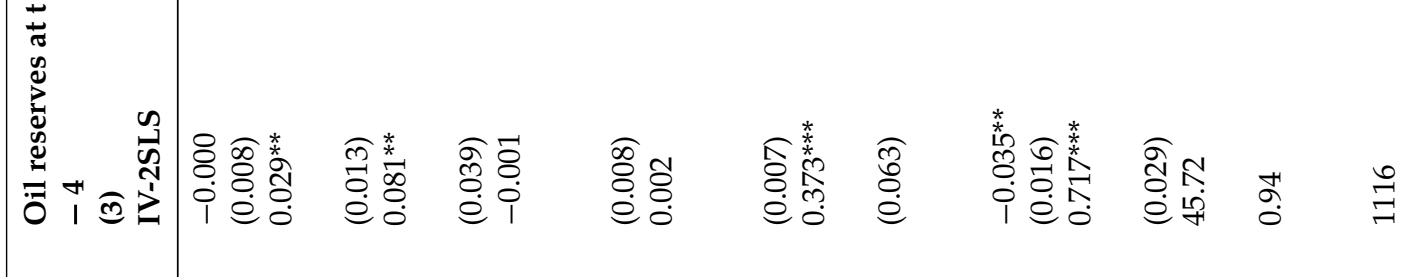

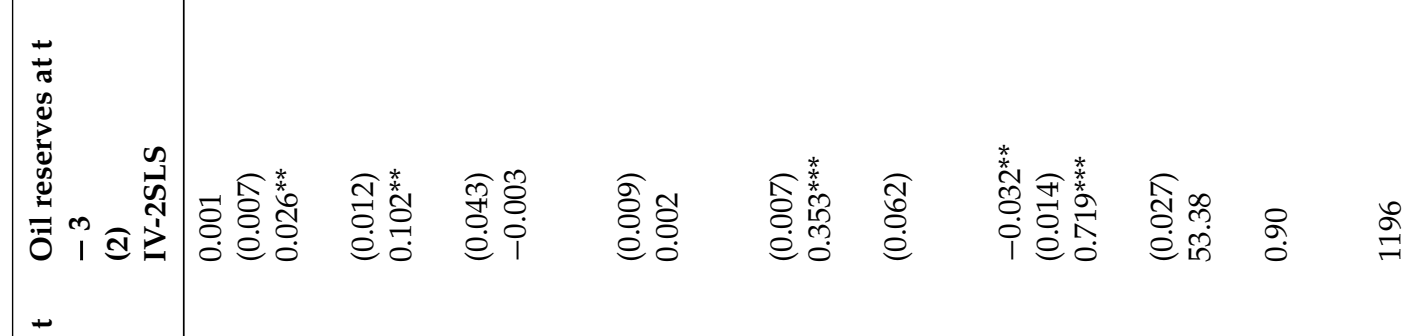

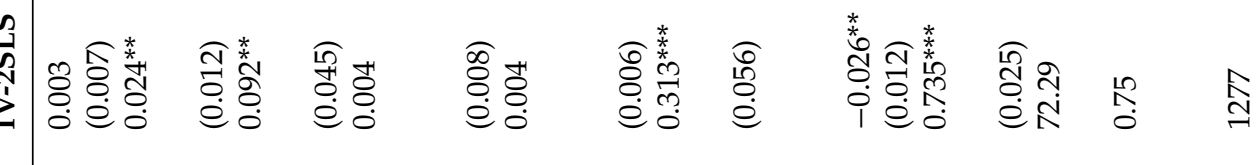

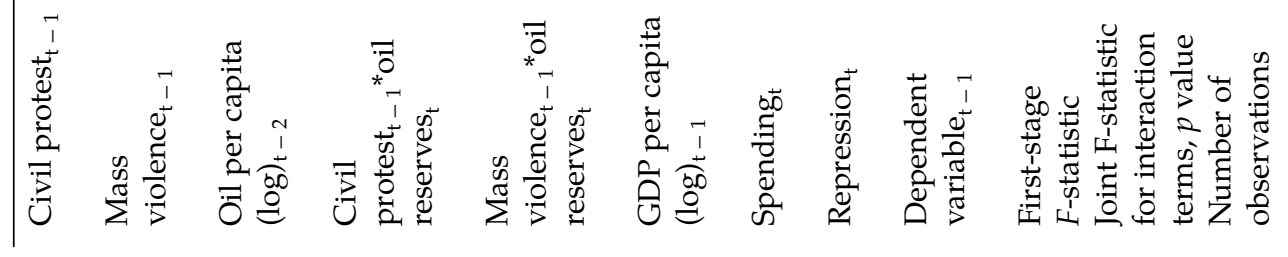




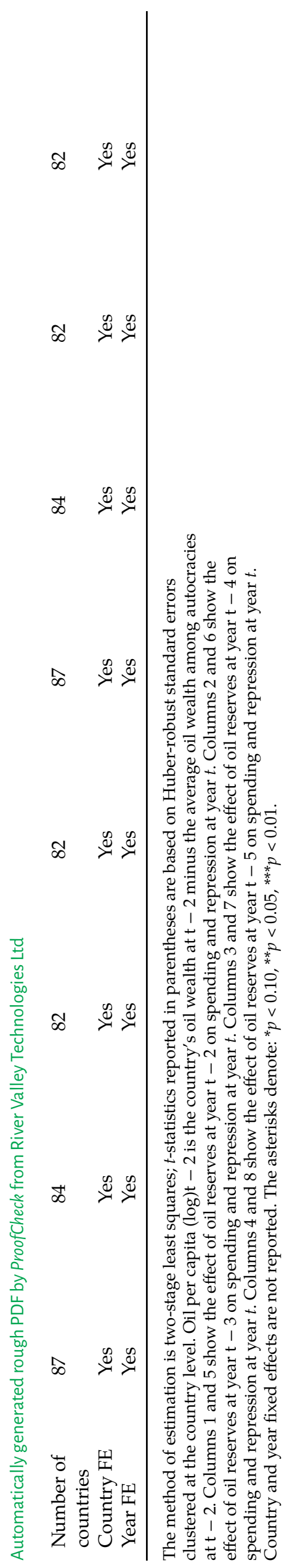


In Table 7, two additional alternative measures for oil wealth are used. One is the oil revenues per capita taken from Ross and Mahdavi (2015). The second is constructed by multiplying the country's (time-invariant) whole period average level of oil production with (time-varying) oil price. Such measure avoids the endogeneity of oil production, by making use of the relative exogeneity of oil prices. The main results remain unchanged.

Table 7: Using oil wealth per capita (Ross \& Mahdavi, 2015) and the value of average of oil production.

\begin{tabular}{|c|c|c|c|c|}
\hline \multirow[t]{2}{*}{ Model } & \multicolumn{2}{|l|}{ Spending } & \multicolumn{2}{|l|}{ Repression } \\
\hline & $\begin{array}{l}\text { Oil wealth (Ross \& } \\
\text { Mahdavi, 2015) } \\
\text { (1) } \\
\text { IV-2SLS }\end{array}$ & $\begin{array}{l}\text { Value of average oil } \\
\text { production } \\
\text { (2) } \\
\text { IV-2SLS }\end{array}$ & $\begin{array}{l}\text { Oil wealth (Ross \& } \\
\text { Mahdavi, 2015) } \\
\text { (3) } \\
\text { IV-2SLS }\end{array}$ & $\begin{array}{l}\text { Value of average oil } \\
\text { production } \\
\text { (4) } \\
\text { IV-2SLS }\end{array}$ \\
\hline Civil protest $_{t-1}$ & $\begin{array}{l}0.012 \\
(0.009)\end{array}$ & $\begin{array}{l}0.004 \\
(0.008)\end{array}$ & $\begin{array}{l}0.119^{* *} \\
(0.058)\end{array}$ & $\begin{array}{l}0.168^{*} \\
(0.087)\end{array}$ \\
\hline Mass violence $_{t-1}$ & $\begin{array}{l}0.019^{*} \\
(0.011)\end{array}$ & $\begin{array}{l}0.020^{*} \\
(0.012)\end{array}$ & $\begin{array}{l}0.232^{* * *} \\
(0.071)\end{array}$ & $\begin{array}{l}0.276^{* * * *} \\
(0.075)\end{array}$ \\
\hline $\begin{array}{l}\text { Oil per capita } \\
(\log )_{t-2}\end{array}$ & $\begin{array}{l}0.032^{* * *} \\
(0.012)\end{array}$ & $\begin{array}{l}0.123^{* * *} \\
(0.035)\end{array}$ & $\begin{array}{l}0.119 \\
(0.077)\end{array}$ & $\begin{array}{l}0.062 \\
(0.271)\end{array}$ \\
\hline $\begin{array}{l}\text { Civil } \text { protest }_{t-1}{ }^{*} \text { oil } \\
\text { per capita }_{t-2}\end{array}$ & $\begin{array}{l}0.001 \\
(0.004)\end{array}$ & $\begin{array}{l}0.001 \\
(0.001)\end{array}$ & $\begin{array}{l}-0.044^{*} \\
(0.023)\end{array}$ & $\begin{array}{l}0.000 \\
(0.011)\end{array}$ \\
\hline $\begin{array}{l}\text { Mass violence } \\
\text { per capita }_{t-2}{ }^{*} \text { oil }\end{array}$ & $\begin{array}{l}0.002 \\
(0.003)\end{array}$ & $\begin{array}{l}0.000 \\
(0.001)\end{array}$ & $-0.038^{*}$ & $-0.015^{* *}$ \\
\hline GDP per capita t $-1_{1}$ & $\begin{array}{l}0.000^{* *} \\
(0.000)\end{array}$ & $\begin{array}{l}0.000^{* *} \\
(0.000)\end{array}$ & $\begin{array}{l}-0.000 \\
(0.000)\end{array}$ & $\begin{array}{l}-0.000 \\
(0.000)\end{array}$ \\
\hline Spending $_{t}$ & & & $\begin{array}{l}-0.110 \\
(0.145)\end{array}$ & $\begin{array}{l}-0.086 \\
(0.154)\end{array}$ \\
\hline Repression $_{t}$ & $\begin{array}{l}-0.032^{* * *} \\
(0.013)\end{array}$ & $\begin{array}{l}-0.033^{* * *} \\
(0.012)\end{array}$ & & \\
\hline $\begin{array}{l}\text { Dependent } \\
\text { variable }_{t-1}\end{array}$ & $\begin{array}{l}0.808^{* * *} \\
(0.031)\end{array}$ & $\begin{array}{l}0.812^{* * *} \\
(0.030)\end{array}$ & $\begin{array}{l}0.384^{* * *} \\
(0.042)\end{array}$ & $\begin{array}{l}0.384^{* * *} \\
(0.043)\end{array}$ \\
\hline First-stage $F$-statistic & 83.46 & 77.84 & 609.98 & 654.77 \\
\hline $\begin{array}{l}\text { Joint F-statistic for } \\
\text { interaction terms, } p \\
\text { value }\end{array}$ & 0.84 & 0.66 & 0.09 & 0.09 \\
\hline $\begin{array}{l}\text { Number of } \\
\text { observations }\end{array}$ & 1325 & 1326 & 1325 & 1326 \\
\hline Number of countries & 89 & 89 & 89 & 89 \\
\hline Country FE & Yes & Yes & Yes & Yes \\
\hline Year FE & Yes & Yes & Yes & Yes \\
\hline
\end{tabular}

The method of estimation is two-stage least squares; $t$-statistics reported in parentheses are based on Huber-robust standard errors clustered at the country level. Oil per capita $(\log ) t-2$ is the country's oil wealth at $t-2$ minus the average oil wealth among autocracies at $t-2$. Columns 1 and 3 reports estimate using oil wealth variable from Ross and Mahdavi (2015). Columns 2 and 4 reports estimates using the country's (time-invariant) whole period average level of oil production multiplied by time varying oil price. Country and year fixed effects are not reported. The asterisks denote: ${ }^{*} p<0.10,{ }^{* *} p<0.05,{ }^{* * *} p<0.01$.

Additional robustness checks are reported in Table 8. First, the measure for government spending in current prices used in our baseline specification is replaced by its counterpart measure as a percentage of GDP. One advantage of this measure is that it includes an indirect measure of the economic size of the country instead of controlling for it separately in the model using real GDP per capita. Therefore, GDP per capita is dropped. The downside, however, is that it could make it difficult to remove business cycles effects given that we are look at year-to-year effects. In other word, it may be hard to decide whether the estimated result is due a change in public spending (numerator) or in GDP (denominator). In column 1, the estimated coefficient for mass violence is positive, but statistically insignificant, whereas the coefficient for civil protest is positive and statistically significant. This could be due to the balancing forces between simultaneous changes in public spending and their base GDP. Recall, civil protest has no significant impact on public spending as shown in our main model, whereas it can have negative effects on the GDP. Hence, reducing the GDP could increase the share of public spending to GDP in face of civil protest, but not the absolute size of public spending. The results in column 2 for the repression model remain the same. Second, Political Terror Scale (PTS) is used as an alternative indicator 
for repression in columns 3 and 4 (Gibney \& Dalton, 1996; Wood \& Gibney, 2010). The PTS ranges from 1 to 5 , with high values indicating high levels of terror. Results remain robust to this specification.

Table 8: Using government expenditures (\% of GDP) and using Political Terror Scale.

\begin{tabular}{|c|c|c|c|c|}
\hline \multirow[t]{2}{*}{ Model } & \multicolumn{2}{|l|}{ Spending } & \multicolumn{2}{|l|}{ Repression } \\
\hline & $\begin{array}{l}\text { Gov. exp. }(\% \text { of } \\
\text { GDP) } \\
\text { (1) } \\
\text { IV-2SLS }\end{array}$ & $\begin{array}{l}\text { PTS } \\
\text { (2) } \\
\text { IV-2SLS }\end{array}$ & $\begin{array}{l}\text { Gov. exp. (\% of } \\
\text { GDP) } \\
\text { (3) } \\
\text { IV-2SLS }\end{array}$ & $\begin{array}{l}\text { PTS } \\
\text { (4) } \\
\text { IV-2SLS }\end{array}$ \\
\hline Civil protest $_{t-1}$ & $\begin{array}{l}0.143^{* *} \\
(0.072)\end{array}$ & $\begin{array}{l}0.016 \\
(0.010)\end{array}$ & $\begin{array}{l}0.113^{* *} \\
(0.056)\end{array}$ & $\begin{array}{l}0.063^{* *} \\
(0.032)\end{array}$ \\
\hline Mass violence $_{t-1}$ & $\begin{array}{l}0.063 \\
(0.214)\end{array}$ & $\begin{array}{l}0.020^{*} \\
(0.011)\end{array}$ & $\begin{array}{l}0.210^{* * * *} \\
(0.069)\end{array}$ & $\begin{array}{l}0.116^{* * *} \\
(0.036)\end{array}$ \\
\hline Oil per capita $(\log )_{t-2}$ & $\begin{array}{l}0.357^{*} \\
(0.205)\end{array}$ & $\begin{array}{l}0.045^{* * *} \\
(0.012)\end{array}$ & $\begin{array}{l}0.038 \\
(0.065)\end{array}$ & $\begin{array}{l}0.033 \\
(0.023)\end{array}$ \\
\hline${\text { Civil } \text { protest }_{t-1}{ }^{*} \text { oil per capita }}_{t-2}$ & $\begin{array}{l}0.050 \\
(0.031)\end{array}$ & $\begin{array}{l}0.002 \\
(0.004)\end{array}$ & $\begin{array}{l}-0.046^{*} \\
(0.024)\end{array}$ & $\begin{array}{l}-0.016 \\
(0.013)\end{array}$ \\
\hline $\begin{array}{l}\text { Mass violence }_{t-1}{ }^{*} \text { oil per } \\
\text { capita }_{t-2}\end{array}$ & $\begin{array}{l}-0.081 \\
(0.096)\end{array}$ & $\begin{array}{l}0.005 \\
(0.003)\end{array}$ & $\begin{array}{l}-0.039^{*} \\
(0.021)\end{array}$ & $\begin{array}{l}-0.019 \\
(0.013)\end{array}$ \\
\hline GDP per capita $\mathrm{t}_{\mathrm{t}-1}$ & & $\begin{array}{l}0.0001^{* *} \\
(0.000)\end{array}$ & & $\begin{array}{l}-0.0001^{* * *} \\
(0.000)\end{array}$ \\
\hline Spending $_{t}$ & & & $\begin{array}{l}0.016 \\
(0.012)\end{array}$ & $\begin{array}{l}-0.075 \\
(0.077)\end{array}$ \\
\hline Repression $_{\mathrm{t}}$ & $\begin{array}{l}-0.145 \\
(0.192)\end{array}$ & $\begin{array}{l}-0.050^{* *} \\
(0.023)\end{array}$ & & \\
\hline Dependent variable $_{t-1}$ & $\begin{array}{l}0.676^{* * *} \\
(0.036)\end{array}$ & $\begin{array}{l}0.791^{* * *} \\
(0.037)\end{array}$ & $\begin{array}{l}0.391^{* * * *} \\
(0.040)\end{array}$ & $\begin{array}{l}0.456^{* * *} \\
(0.040)\end{array}$ \\
\hline First-stage $F$-statistic & 83.64 & 126.49 & 338.93 & 474.69 \\
\hline $\begin{array}{l}\text { Joint F-statistic for interaction } \\
\text { terms, } p \text { value }\end{array}$ & 0.13 & 0.29 & 0.05 & 0.18 \\
\hline Number of observations & 1364 & 1343 & 1364 & 1343 \\
\hline Number of countries & 90 & 91 & 90 & 91 \\
\hline Country FE & Yes & Yes & Yes & Yes \\
\hline Year FE & Yes & Yes & Yes & Yes \\
\hline
\end{tabular}

The method of estimation is two-stage least squares; $t$-statistics reported in parentheses are based on Huber-robust standard errors clustered at the country level. Oil per capita $(\log ) t-2$ is the country's oil wealth at $t-2$ minus the average oil wealth among autocracies at $t-2$. Columns 1 and 3 report estimates when general government expenditures (\% GDP) is used; columns 2 and 4 report estimates using political terror scale as an indicator for repression. Country and year fixed effects are not reported. The asterisks denote: ${ }^{*} p<0.10$, ${ }^{* *} p<0.05,{ }^{* * *} p<0.01$.

\section{Conclusion}

The first implication of this study is that the type of threat matters when it comes to the dictator's decision to perceive a certain strategy. This rather takes us away from the general notion contending repression and spending as natural traits of dictatorships, to conceiving them as means ready for employment when needed and subject to tradeoffs with other strategies depending on the dictator's time horizon. In line with Wintrobe (1998) and Annett (2001), the short run responses to political threats are either spending or repression. The empirical results predict a rather simultaneous increase in both spending and repression in face of mass violence, and that repression is preferred over spending in case of mass protests. As such, instead of engaging in spending or repression in mutually exclusive fashion as indicated in previous studies, the novelty of the results here lies in revealing a third possibility of mixing between both depending on the intensity of the threat. Furthermore, repression is found to crowd out the financial resources available to support public spending, whereas public spending does not seem to reduce the level of repression employed. In other words, repression can act as a substitute for spending, but spending cannot substitute repression.

The second implication suggests that oil dictatorship are in the end dictators who gained their name because they cannot be removed by popular vote (Ghandhi \& Przeworski, 2007), but the difference lies in their source and size of their incomes. Hence, under the same circumstances, they will always follow the same dictatorial 
strategies independent of the size of their oil wealth. As the results show, the size of oil wealth may have a relative impact on increasing spending, but only at low and intermediate levels of threats, but as the threats intensify, the effect of oil wealth dissipates and oil dictatorships behave the same as their non-oil counterparts. Additionally, oil wealth showed no impact on repression, whether independent or conditional on threats. The gives a rise to an important conclusion that even if oil wealth might have the potential to alter the distributive and repressive capacities of dictatorships, there is still no strong evidence to believe that such endowments can make countries less repressive or drives them to substitute spending for force when faced by severe power challenges.

In a broader perspective, this study offers an extension to Wintrobe (1998) modeling of dictatorial response to negative shocks that reduce the populace's loyalty to the regime. By differentiating between the intensities of mass threats, the corresponding responses are extended to include not only exclusive resorting to repression or spending, but also a mix between both. Furthermore, the size of financial resources can allow for differences in the levels of employed repression and spending in face of the same threat. In this regard, it was shown oil dictators differ in the levels of the employed spending and repression at very low and intermediate levels of threats.

These results are quite useful in understanding the dictatorial behavior in different settings and offers further explanation for the duration of authoritarian regimes, especially in oil dependent countries. Furthermore, instead of identifying the strategies for political survival, equally important is the understanding of the circumstances under which dictators can choose their responding mechanism. The disaggregation of threats into elites and masses, small scale, peaceful and violent is useful in studying not the dictators' behavior, but also the reaction of different society groups to dictatorial policies. Additionally, specifying the dictator's time horizon gives more insights about the tradeoff between perused policies. For instance, financial constraints can reduce the ability of the leader to sustain both spending and repression in the long run, a situation that could drive him to crackdown on freedoms or offer political concessions to contain future threats. A point of departure would be through looking at the institutional setting and the composition of opposition groups in these states. Although I made no argument about the extent of the organization of political opposition, it is worthy to study that. As pointed by Smith (2004), oil dictatorships might have developed non-repressive mechanisms that allow them to stay in power. Finally, the typology of oil dictatorships based on the size of their rents and population can be incorporated in other studies such as foreign aid. The benchmark should not be the degree on dependence on the source of income, but the capacity to distribute on the population. More research is needed to explore whether the same results can be reached with other types of rents mainly minerals and foreign aid.

\section{Acknowledgments}

For comments, I thank Toke S. Aidt, Marc Klemp, Timur Kuran, James Hollyer, Kai Gehring, Mario Ferrero, Mathias Basedau, Endrich Grundlach, Jerg Gutmann, Urlich Fritsche, Melanie Krause, Kunal Sen, Károly Mike, Tommy Krieger, Christian Bjornskov, two anonymous referees, all participants at the 2018 International Conference on the Political Economy of Democracy and Dictatorship (University of Münster), the 2018 Prague Conference on Political Economy, the 2018 Silvaplana Workshop on Political Economy, the 2018 INFER Annual Conference (University of Göttingen), the 2017 German-Arab Masters Programs (GAMP) Alumni meeting, and I thank Jennifer Gandhi and Courtenay Conrad for sharing their data.

\section{Notes}

1 See Andersen \& Aslaksen, 2013; Anyanwu \& Erhijakpor, 2014; Aslaksen, 2010; Cuaresma, Oberhofer, \& Raschky, 2010; Morrison, 2015; Ramsay, 2011; Ross 2001; 2009; Smith, 2004; Tsui, 2011; Ulfelder, 2007; Wiens, Poast, \& Clark, 2014; Wright et al., 2013.

2 As it will be explained below, oil wealth refers to the value of oil production in per capita terms. I also use the terms oil wealth, oil abundance and financial resources interchangeably.

3 F. Gause (2011)

4 See "Tunisia pushes out its strongman: could other Arab countries follow?" Time, 14 January 2011.

5 A third possible strategy is freedom concessions, which will considered in the robustness checks in relation to spending and repression. 6 As perfectly put by Wintrobe (1998) "the optimal response to a fall in loyalty is to expand repression in the short run". In this regard I make no distinction between tinpots' and totalitarians' short run responses to a sudden fall in loyalty, as depicted in Wintrobe's model. Since my argument is based on the intensity of the threat (i.e. negative shock) rather than on the type of dictator, a thing that was not tackled in Wintrobe's model.

7 Empirical studies managed to find that oil pushes downward the levels of democracy, or similarly increase authoritarian levels, and such impact is driven by large scale distribution rather than repression (Anyanwu \& Erhijakpor, 2014; Aslaksen, 2010; Ramsay, 2011; Ross, 2001; Tsui, 2011; Wantchekon \& Jensen, 2004). Other studies (Andersen \& Aslaksen, 2013; Cuaresma et al., 2010; Morrison, 2015; Ross, 2009; Smith, 2004; Ulfelder, 2007; Wiens et al., 2014; Wright et al., 2013). 
8 The idea that a higher oil wealth per capita can be associated with more redistribution is analogues to De Mesquita, Smith, Siverson, and Morrow (2003) theory on the ruler's choice between providing private or public goods. The choice is based on the relative size of the wining coalition to the selectorate. The bigger the selectorate (in our case the population) relative to the winning coalition (in our case the elites), the more costly is to provide public goods to the whole population, and the ruler will opt for more private goods distribution to his selected supporters.

9 The period of analysis is restricted to 2006, because of the data availability of UCDP / PRIO Armed Conflict Dataset 3.1 covering incidences of civil strife (Gleditsch et al., 2002).

10 Only the last period is truncated to 2006. The regions are: Middle East and North Africa, Latin America, Asia, Sub-Saharan Africa, and Europe.

11 This corresponds to a monetary value of current US $\$ 1000$ or more in per capita terms. The same cutoff points were given by Cammett, Diwan, Richards, and Waterbury (2015) and Basedau and Lacher (2006).

12 Annett (2001) and Escribà-Folch (2013).

13 Political instabilities in a country could be driven by many causes (e.g. inequality, income shocks, ..., etc.) and in this model, the focus is on the existence of instabilities rather than investigating the causes. Hence, political instabilities are not instrumented. However, to account for periods when low oil prices negatively affects state revenues and the dictator's ability to buy off opposition, in the robustness checks I restrict the sample to only oil bust years.

14 The original CGV dataset consists of around 130 autocratic regimes. Unfortunately, I only managed to include 88 countries given the lack of data on consumption and repression for the dropped countries during the sample period. The excluded countries compromise some of the major oil producers including Saudi Arabia, Libya, Angola and Equatorial Guinea. Although this might get us into a potential selection bias, I argue that this shall not of a major concern given that most of the dropped countries ( 28 out of 42 countries) has experienced an uninterrupted autocratic rule during the sampled period and score very low levels of political instabilities. Nevertheless, I acknowledge the fact that the unavailability of data for some countries presents a serious limitation to this paper.

15 For example Bosnia (1992-1995) was at a state of civil war, thus lacking 'any sovereign political authority' (Svolik, 2012)

16 To address endogeneity issues, I also consider using oil reserves and time-invariant measure for the level of oil production as alternative measures for oil wealth.

17 To give further insights on the distinct conditional effects of oil wealth and GDP on the trade-off between repression and consumption, I report in the online appendix the impact of political instabilities conditional upon the initial level of the GDP, while controlling for oil wealth.

18 A high correlation was found between $(\log )$ oil wealth per capita and $(\log )$ GDP per capita of about $70 \%$ along with a high variance inflation error (VIF) of 90 points, causing the model to suffer from multicollinearity and reducing the precision of the estimated coefficients. Such high correlation is expected to exist since oil wealth contributes greatly to a country's economic growth, especially in non-developing countries. Hence, GDP per capita is used instead of its natural $\log$ ( $52 \%$ correlation and VIF is of 2 points). It should be noted that dropping GDP per capita leave our main results unchanged (results available upon request).

19 See also Aslaksen, 2010; Basedau \& Lacher, 2006; Ramsay, 2011; Ross, 2001; Smith, 2004; Tsui, 2011; Ulfelder, 2007; Wantchekon \& Jensen, 2004.

20 Given that, the two-stage least squares method becomes more preferable to system-GMM, where the number of instruments in the latter method tend to increase with $T$ leading to overfitting and failing to expunge the endogeneity of the variable. Hence, unreliable estimates could be produced, especially if N gets smaller (Roodman, 2009a,Roodman).

21 Other robustness checks are reported in Online Appendix C including: the use of another classification for autocracy; adding additional instruments; drop dynamic effects; and adding additional economic and demographic variable.

22 Furthermore, if there are time-variant factors that jointly affect the explanatory and the response variables, adding year fixed effects removes any specific association between both variables, which are already controlled for.

\section{References}

Acemoglu, D., \& Robinson, J. A. (2000). Why did the west extend the franchise? Quarterly Journal of Economics, 115, 1167-1199.

Acemoglu, D., Ticchi, D., \& Vindigni, A. (2010). A theory of military dictatorships. American Economic Journal, Macroeconomics, 2, 1-42.

Alesina, A., \& Perotti, R. (1996). Income distribution, political instability and investment. European Economic Review, 40, $1203-1228$.

Andersen, J. J., \& Aslaksen, S. (2013). Oil and political survival. Journal of Development Economics, 100, 89-106.

Annett, A. (2001). Social fractionalization, political instability, and the size of government. IMFStaff Papers, 48, 561-592.

Anyanwu, J., \& Erhijakpor, A. (2014). Does oil wealth affect democracy in Africa? African Development Review, 26, 15-37.

Aslaksen, S. (2010). Oil and democracy: More than a cross-country correlation? Journal of Peace Research, 47, 421-431.

Barsky, R., \& Kilian, L. (2004). Oil and the Macroeconomy since the 1970s. Journal of Economic Prespectives, 18, 115-134.

Basedau, M., \& Lacher, W. (2006). A paradox of plenty? Rent distribution and political stability in oil states. GICA Working Paper, No. 21, Hamburg: GICA.

Beblawi, H., \& Luciani, G. (1987). The rentier state. Routledge, London: Taylor \& Francis Group.

Beck, N., \& Katz, J. N. (2011). Modeling dynamics in time-series cross-section political economy data. Annual Review of Political Science, 14, 331352.

Blanco, L., \& Grier, R. (2009). Long Live Democracy: The Determinants of Political Instability in Latin America. The Journal of Development Studies, 45, 76-95.

Blundell, R., \& Bond, S. (1998). Initial models and moment restrictions in dynamic panel data models. Journal of Econometrics, 87, 115-143.

Cammett, M. C., Diwan, I., Richards, A., \& Waterbury, J. (2015). A political economy of the Middle East (4th ed.). Boulder, CO: Westview Press.

Caselli, F., \& Cunningham, T. (2009). Leader behavior and the natural resource curse. Oxford Economic Papers, 61, 628-650.

Caselli, F., \& Tesei, A. (2016). Resource windfalls, political regimes and political stability. The Review of Economics and Statistics, 98, 573-590.

Cheibub Jose, A., Chandi, J., \& Vreeland, J. (2010a). Democracy and dictatorship revisited. Public Choice, 143, 67-101.

Cheibub Jose, A., Chandi, J., \& Vreeland, J. (2010b). Democracy and dictatorship data set. https://netfiles.uiuc.edu/cheibub.

Cingranelli, D., Richards, D., \& Clay, K. (2014). The CIRI human rights dataset. http://www.humanrightsdata.com. 
Conrad, C. R. (2011). Constrained concessions: Beneficent dictatorial responses to the domestic political opposition. International Studies Quarterly, 55, 1167-1187.

Cuaresma, J. C., Oberhofer, H., \& Raschky, P. A. (2010). Oil and the duration of dictatorships. Public Choice, 148, 505-530.

Cukierman, A., Edward, S., \& Tabellini, G. (1992). Seignorage and political instability. American Economic Review, 82, 537-555. Databanks International. (2005). Cross national time series data archive, 1815-2003. http://www.databanksinternational.com/. De Mesquita, B. B., Smith, A., Siverson, R., \& Morrow, J. (2003). The logic of political survival. Cambridge: MIT Press.

Dunning, T. (2008). Crude democracy: Natural resource wealth and political regimes. New York: Cambridge University Press. Elbadawi, I., \& Makdisi, S. (2013). Understanding democratic transition in the Arab world. Economic Research Forum (ERF), 678, 1-48. Escribà-Folch, A. (2013). Repression, political threats, and survival under autocracy. International Political Science Review, 34, 543-60. Gandhi, J. (2008). Political institutions under dictatorship. New York: Cambridge University Press. Gause, F. (2011). Why middle east studies missed the Arab spring: The myth of authoritarian stability. Foreign Affairs, 90, 81-90. Ceddes, B., Wright, J., \& Frantz, E. (2014). Autocratic breakdown and regime transitions: A new data set. Perspectives on Politics, $12,313-331$. Chandhi, J., \& Przeworski, A. (2006). Cooperation, cooptation, and rebellion under dictatorships. Economics \& Politics, 18, 1-26. Chandhi, J., \& Przeworski, A. (2007). Authoritarian institutions and the survival of autocrats. Comparative Political Studies, 40, $1279-1301$. Gibney, M., \& Dalton, M. (1996). The political terror scale. Policy Studies and Developing Nations, 4, 73-84.

Gleditsch, N., Wallensteen, P., Eriksson, M., Sollenberg, M., \& Strand, H. (2002). Armed conflict 1946-2001: A new dataset. Journal of Peace Research, 39, 615-637.

Haber, S., \& Menaldo, V. (2011). Do natural resources fuel authoritarianism? A reappraisal of the resource curse. American Political Science Review, 105, 1-26.

Hibbs Jr, D. (1973). Mass political violence: A cross-national causal analysis. New York: Wiley.

Freedom House. (2016). Freedom in the World Data. https://freedomhouse.org/content/freedom-world-data-and-resources.

Jong-a-Pin, R. (2009). On the measurement of political instability and its impact on economic growth. European Journal of Political Economy, 25, 15-29.

Mahdavy, H. (1970). Patterns and problems of economic development in Rentier states: The case of Iran. In M. A. Cook (Ed.), Studies in the Economic History of the Middle-East, Oxford: Oxford University Press.

Mesquita, B. B., \& Smith, A. (2010). Leader survival, revolutions, and the nature of government Finance. American Journal of Political Science, 54 , 936-950.

Morrison, K. M. (2009). Oil, nontax revenue, and the redistributional foundations of regime stability. International Organization, 63, $107-138$. Morrison, K. (2015). Nontaxation and representation: The fiscal foundations of political stability. New York: Cambridge University Press.

Nickell, S. J. (1981). Biases in Dynamic Models with Fixed Effects. Econometrica, 49, 1417-26.

Perotti, R. (1996). Growth, income distribution and democracy: What the data say. Journal of Economic Growth, 1, 149-187.

Ramsay, K. (2011). Revisiting the resource curse: Natural disasters, the price of oil, and democracy. International Organization, 65, $507-529$.

Roodman, D. (2009a). A note on the theme of too many instruments. Oxford Bulletin of Economics and Statistics, 71, 135-158.

Roodman, D. (2009b). How to do XTABOND2. An introduction to difference and system-GMM in Stata. Stata Journal, 9, 86-136.

Ross, M. (2001). Does oil hinder democracy? World Politics, 53, 325-361.

Ross, M. (2009). Oil and democracy revisited. Mimeo, UCLA.

Ross, M., \& Mahdavi, P. (2015). Oil and gas data, 1932-2014. Harvard Dataverse, V2. Available at: doi: 10.7910/DVN/ZTPWoY.

Smith, B. (2004). Oil wealth and regime survival in the developing world, 1960-1999. American Journal of Political Science, 48, $232-246$.

\section{Svolik, M. (2012). The politics of authoritarian rule. New York: Cambridge University Press.}

Tsui, K. (2010). Resource curse, political entry and deadweight costs. Economics and Politics, 22, 471-497.

Tsui, K. (2011). More oil, less democracy: Evidence from worldwide crude oil discoveries. The Economic Journal, 121, 89-115.

Ulfelder, J. (2007). Natural-resource wealth and the survival of autocracy. Comparative Political Studies, 40, 995-1018.

Vanieries, Y., \& Cupta, D. (1986). Income distribution and sociopolitical instability as determinants of savings: A cross-sectional model. Journal of Political Economy, 94, 873-883.

Vreeland, J. R. (2008). Political institutions and human rights: Why dictatorships enter into the United Nations convention against torture? International Organization, 62, 65-101.

Wantchekon, L., \& Jensen, N. (2004). Resource wealth and political regimes in Africa. Comparative Political Studies, 37, 816-841.

Wiens, D., Poast, P., \& Clark, W. R. (2014). The political resource curse. Political Research Quarterly, 67, 783-794.

Wintrobe, R. (1998). The political economy of dictatorship. New York: Cambridge University Press

Wood, R. M., \& Gibney, M. (2010). The political terror scale (PTS): A re-introduction and a comparison to CIRI. Human Rights Quarterly, 32 , 367-400.

World Bank. (2016). World Development Indicators. https://databank.worldbank.org/data/reports.aspx?source=world-development-indicators. Wright, J., Frantz, E., \& Geddes, B. (2013). Oil and autocratic regime survival. British Journal of Political Science, 45, 287-306.

Supplementary Material: The online version of this article offers supplementary material (DOI: https://doi.org/10.1515/peps-2018-0043). 